\title{
LA TEORÍA DE LA INEXISTENCIA Y SU FALTA DE CABIDA EN EL CÓDIGO CIVIL CHILENO
}

\section{THE THEORY OF INEXISTENCE AND THEIR LACK OF PLACE IN THE CHILEAN CIVIL CODE}

\section{Lilian C. San Martín Neira*}

\begin{abstract}
RESUMEN: El presente trabajo presenta una síntesis histórica de la llamada teoría de la inexistencia de los actos jurídicos y ofrece una refutación de los principales argumentos a su favor. A partir de un análisis histórico dogmático, el trabajo demuestra que la inexistencia, en los términos aceptados por la doctrina chilena, fue deliberadamente excluida por A. BeLlo, quien, consciente de que la nulidad absoluta del acto equivale a su inexistencia, instituyó a aquella como máxima causal de ineficacia, innovando al establecer un plazo de saneamiento, que más bien corresponde a un plazo de extinción de la acción de nulidad absoluta.
\end{abstract}

Palabras clave: Inexistencia, Nulidad absoluta, Ineficacia jurídica, Invalidez del acto jurídico.

ABSTRACT: This paper presents a historical synthesis of the so-called theory of the juridical inexistence and offers a refutation of its principal arguments. From a dogmatic historical analysis, the work seeks to demonstrate that, at least in the terms accepted by the Chilean authors, the inexistence as a legal causal of ineffectiveness was deliberately excluded by A. Bello, who instituted the absolute nullity as maximum causal of ineffectiveness and made an innovation introducing a period of validation, which rather is a time limit for the absolute nullity's action.

Key words: Juridical inexistence, absolute nullity, ineffectiveness, Invalidity of legal act.

\section{INTRODUCCIÓN}

Una de las discusiones clásicas del Derecho civil chileno es la relativa a la llamada teoría de la inexistencia y a la circunstancia de si ella tiene o no cabida en el ordenamiento jurídico nacional, más específicamente en el Código Civil. Esta es una disputa antigua, que sobre la base de argumentos disímiles ha contado con la participación de prestigiosos autores $^{1}$, y gira en torno a la posibilidad de solicitar a los tribunales la declaración de inexistencia de un acto, al margen de la nulidad absoluta e incluso más allá del plazo de saneamiento de esta.

* Licenciada en Ciencias Jurídicas y Sociales, Universidad de Concepción (Chile). Máster y Doctora en "Sistema Jurídico Romanista", Università degli Studi di Roma - "Tor Vergata" (Italia). Profesora de Derecho Civil, Universidad Alberto Hurtado (Chile). Dirección postal: Cienfuegos 41, Santiago. Correo electrónico lsanmar@uahurtado. cl. Este trabajo forma parte del Proyecto Anillo de Investigación Asociativa en Ciencias Sociales, "Estudios Histórico-Dogmáticos de Derecho Patrimonial Privado: una mirada a los artículos de los libros II y IV del Código Civil de Chile". SOC 1111, de Conicyt. Agradezco los valiosos comentarios de los profesores: Jorge Larroucau, Nicolás Rojas y José Miguel Valdivia.

1 Véase, por todos, Claro Solar (1979) pp. 588 ss.; Vodanovic (1945) pp. 514 ss.; Pescio (1958) pp. 186 ss.; Alessandri Besa (1949) pp. 11 ss.; Ducci (1988) pp. 311 ss.; Rodríguez Grez (1995) pp. 11 ss.; Lecaros (1997) pp. 3 ss.; Vial del Río (2003) pp. 237 ss.; Domínguez (2012) pp. 175 ss.; Baraona (2012) pp. 29 ss. 
Los partidarios de la inexistencia como sanción distinta de la nulidad conciben al acto jurídico como un ser vivo, que puede nacer o no nacer, estar sano o enfermo. El acto que no ha nacido, sería inexistente, el que nace enfermo nulo². A nuestro juicio, esta distinción no se hace cargo de que lo importante para el tráfico y la seguridad jurídica no es determinar la vida del acto, sino establecer el destino de las consecuencias prácticas haya generado el acto anómalo. Por otro lado, los argumentos literales utilizados a favor de la inexistencia admiten diversas interpretaciones o conclusiones y, por tanto, no son concluyentes. Finalmente, tales argumentos no se condicen con los antecedentes ni con la historia del Código Civil.

Por lo anterior, este trabajo se refiere al hecho de que en el Código Civil chileno no tiene cabida la llamada teoría de la inexistencia, pues la noción de ineficacia que ella propone era conocida por el codificador, quien era consciente de que la nulidad absoluta del acto equivalía a su inexistencia, pero innovó al establecer un plazo para el ejercicio de la acción de nulidad absoluta, situación que denominó saneamiento de la nulidad, pero que más bien corresponde a un plazo de extinción de la acción.

En la exposición se tendrán especialmente en consideración los antecedentes e interpretación de la codificación francesa en lo relativo a las nulidades, pues existe consenso en torno a que allí están las bases de la discusión sobre el argumento ${ }^{3}$. Asimismo, se utilizará como parámetro de comparación la situación en el Derecho español e italiano, pues en la doctrina nacional son frecuentes las remisiones a las reglas e interpretaciones jurisprudenciales y doctrinarias de estos ordenamientos.

\section{NULIDAD RADICAL, NULIDAD DE PLENO DERECHO E INEXISTENCIA COMO EQUIVALENTES CONCEPTUALES DE "NULIDAD ABSOLUTA"}

\section{A. Algunas noticias sobre el sistema de nulidades en Derecho romano e INTERMEDIO \\ Los antecedentes del sistema de nulidades francés (incluida la inexistencia) se remon-} tan al Derecho romano y, en épocas más recientes, a la doctrina y jurisprudencia imperante en el llamado Ancien Droit. De ahí que sean necesarios algunos breves alcances al respecto.

Si bien los juristas romanos no elaboraron un sistema de ineficacia de los actos jurídicos, la doctrina romanista es uniforme en que la invalidez de los actos tenía en Roma una doble recepción: en Derecho civil y en Derecho pretorio ${ }^{4}$. En Derecho civil, los juristas se referían al acto señalando que este "no existe" o que "no hay nada" (nullus momenti est o

\footnotetext{
2 Esta idea forma parte de lo que la doctrina francesa ha llamado "teoría clásica de las nulidades". Por todos vid Robleda (1964) pp. 53 ss.; Thibierge (2010) pp. 329 ss.

3 Sin perjuicio de que las obras fundamentales han sido consultadas directamente y dado que el objetivo central de este trabajo es el análisis de la realidad nacional, en la exposición del Derecho francés se seguirán principalmente los resúmenes presentados en: RENARD y VieUjeAn (1962) pp. 243-294; GAUdet (1995) pp. 291-363; Boudot (2009) pp. 79-98.

4 Vid Di Paola (1966); Brutti (1972); Masi (1978); Martín Pérez (1995) p. 81; Coing (1996), t. I, p. 524; Zimmermann (1996) p. 678 ss.; Talamanca (1998); Iglesias (2001) p. 115; San Filippo (2002) p. 101; DíezPicazo (2007) p. 556; Kleine (2010) pp. 15 ss.; Talamanca (2013) p. 111; GuZmán Brito (2013), t. II p. 17 ss.
} 
nullum actum est $)^{5}$. De esta manera, la calificación de un negocio en términos de nulidad expresaba la "inexistencia" del mismo ${ }^{6}$ y, por lo mismo, operaba ipso iure, es decir, no podía iniciarse un juicio con base en el contrato nulo, pues no existía la posibilidad de poner en movimiento una actio $^{7}$. Los efectos a que de hecho hubiera dado lugar el acto nulo se eliminaban mediante acciones destinadas a su remoción, sin que hubiera necesidad de solicitar la "declaración" de nulidad".

Por el contrario, existían casos en que el acto, jurídicamente existente y civilmente válido, era sin embargo ineficaz en el Derecho pretorio, ineficacia que se hacía efectiva mediante una exceptio o bien mediante la denegatio actionis con las cuales se paralizaba la acción dirigida a obtener la ejecución del acto ${ }^{9}$, pero este permanecía vigente en el plano del ius civilis $^{10}$. En estos casos los juristas sostenían que el acto es inútil (inutilis), porque si bien existe no genera obligación civil ni natural ${ }^{11}$.

Finalmente, había casos en los que se permitía dejar sin efecto un acto existente, válido y eficaz, que ya había sido ejecutado. Esto se lograba por medio de un decreto rescisorio emanado del pretor en procedimiento de restitutio in integrum ${ }^{12}$, que tenía por efecto

\footnotetext{
5 Martín Pérez (1995) p. 81; Zimmermann (1996) p. 679; Guzmán Brito (2013), t. II, p. 17.

${ }^{6}$ En este sentido, contraponiendo la concepción moderna de 'nulidad' con la 'nulidad' romana, afirma Talamanca "il modo in cui i si esprimono i giuristi romani rispetto ai negozi nulli è, dal punto di vista terminológico, diferente da quello attuale. Noi ci riferiamo ad un "negozio nullo" e quindi affermiamo l'essistenza di qualcosa, ulteriormente qualificata con l'aggettivo nullo, predicandone la mancanza di effetti. Nella terminologia romana, dicendo nulla es venditio, nulla est mancipatio, nullum est legatum, si affermava, invece, che non essisteva il negozio, in quanto tali espressioni erano equivalente a quelle non ese venditionem, mancipationem, legatum ("non essiste la vendita, la mancipazione, il legato"): in latino, infatti, nullus è soltanto un aggettivo indefinito che nega la esistenza del nome cui si appone". Cfr. TAlamanca (2013) p. 111. Este mismo razonamiento se encuentra en Talamanca (1990) p. 225-226. Esta idea es uniformemente aceptada por la doctrina romanista actual vid por todos DI Paola (1966) pp. 69 ss., especialmente p. 86; Brutti (1972) p. 570; Masi (1978) p. 859 ss.; GUzMán Brito (2013), t. II, p. 18.

7 Para entender el sistema de nulidades romano es necesario tener presente la estructura del proceso formulario y su bipartición en fase in iure y apud iudicem. La primera se llevaba a cabo frente al pretor, quien decidía si, atendidos sus fundamentos, correspondía o no conceder la acción, pero ello no significaba acoger las peticiones del actor. La segunda fase se llevaba a cabo frente al juez, quien era un privado designado por las partes, este decidía si acoger o no las peticiones del actor. De esta manera, cuando el actor solicitaba el cumplimiento de lo acordado en virtud de un acto nulo, el pretor no concedía la acción y el juicio no tenía lugar, en este sentido puede decirse que la nulidad operaba ipso iure. Por el contrario, había casos en que el acto era perfectamente válido conforme al ius civilis y, por tanto, había lugar al ejercicio de la acción que exigía el cumplimiento, pero el pretor hacía uso de su facultad de denegatio actiones o bien concedía al demandado una exceptio en este caso el juicio sí tenía lugar, el juez debía decidir cuál de las partes tenía razón. Finalmente, en ciertos casos excepcionales se permitía al deudor recuperar lo que hubiera pagado en virtud de un acto considerado anómalo (por ejemplo, contratos con menores de edad) y en estos casos operaba rescisión, que tenía la virtud de retrotraer a las partes al estado anterior a la celebración del acto. Véase Brutti (1972) pp. 572 ss.; Zimmermann (1996) pp. 678 ss.; Díez-Picazo (2007) p. 555.; GuZmán Brito (2013), t. I pp. 229 ss. y t. II, p. 17 ss.

8 Iglesias (2001) p. 114;

9 Kaser (1982) p. 55; GuZmán Brito (2013), t. II, p. 19.

10 Talamanca (1998) p. 12; Martín Pérez (1995) pp. 82 ss.; Guzmán Brito (2013), t. II, p. 19

11 GuZmán Brito (2013), t. II, p. 19.

12 Ghestin (1988) p. 873; Martín Pérez (1995) p. 88; Zimmermann (1996) p. 680; GuZmán Brito (2013) p. 19.
} 
restablecer a las partes al estado anterior a la celebración del acto ${ }^{13}$. En este caso el pretor concedía además ciertas acciones para excluir los efectos que el negocio de hecho hubiera generado $^{14}$.

Con la unificación del ius civilis y del ius honorarium, así como la desaparición del proceso formulario y su reemplazo por la cognitio extraordinem, el sistema descrito deja de tener alguna lógica interna; sin embargo las soluciones serían fragmentariamente recogidas por la compilación justinianea. Esto llevará a que durante el ius commune el sistema de las nulidades represente una verdadera encrucijada para los juristas medievales, quienes intentarán encontrar una justificación sustantiva que explique la diversidad de soluciones al interior del Corpus Iuris, como si se tratara de un sistema único, sin considerar la división entre ius civilis y ius honorarium ${ }^{15}$, ni la influencia del sistema procesal sobre las soluciones sustantivas. En este proceso los juristas recurren a los conceptos de "nulidad" [nullitas] y "anulación" [annullandi] ${ }^{16}$. De esta manera, la exceptio y la restitutio in integrum corresponden a una verdadera anulación judicial del acto ${ }^{17}$. Algunos autores extraen de esta constatación el siguiente razonamiento lógico: "el acto sujeto a exceptio o a la restitutio in integrum no es nulo ni válido, más bien ocupa una posición intermedia. Él es anulable y, por tanto, se distingue del acto radicalmente nulo"18, cuya nulidad opera ipso iure. Sin embargo, no logran encontrar la razón de estas diferencias y las opiniones son de la más variada índole, al punto que se ha llegado a afirmar que, intentando encontrar la diferencia entre nulidad ipso iure y anulabilidad, los juristas medievales eran "como hombres ciegos, en una habitación obscura, buscando un gato negro, que no estaba ahî"19.

En síntesis, con la fusión entre Derecho civil y Derecho pretorio y el cambio en la estructura del proceso, el sistema no se justifica por sí mismo y carece de sentido práctico. Sin embargo, al interpretar el Corpus Iuris, los juristas intentan encontrar una justificación racional y sustantiva para la diferenciar entre nulidad radical o ipso iure y anulabilidad.

13 Cfr. Gaudet (1995) p. 299. Se ha definido a la restitutio in integrum como "un recurso de carácter extraordinario concedido por el pretor con el fin de rescindir los efectos de un acto y restablecer una situación existente que se ha visto modificada por ese determinado acto”. Cfr. Buigues Oliver (1992) p. 21.

14 KASER (1982) p. 56.

15 Esta situación se presentó también en la pandectística alemana, Di PAOLA (1966) p. 1.

16 Colng (1996), t. I, p. 524; KLein (2010) pp. 44 ss. Sobre este proceso señala Brutti: “il cosidetto proceso di fusione degli ordinamenti classici porterà a una distinzione tra fattispecie inesistente e fattispecie $i$ cui effetti sono paralizzati attraverso strumenti di stampo pretorio. Ma la compilazione giustinianea ne conserverà le contradditorie testimonianze e la tradizione romanistica elaborerà su di esse una serie di gradazioni dell'invalidità comprensivi anche dei meccanismi pretori". Cfr. BRUTTI (1972) p. 573.

17 Gaudet (1995) p. 300.

18 Gaudet (1995) p. 300. La distinción así expuesta no es solo teórica, ella tiene un impacto en el procedimiento. Mientras que es inútil hacer anular un acto nulo, más bien se lo puede ignorar sin más formalidades; si el acto es anulable, es necesario proceder a su anulación antes de ignorarlo. Por ejemplo, en caso de testamento nulo, el heredero abintestato puede proceder directamente a la petición de herencia, en que caso que el testamento sea anulable, antes de ejercer la acción de petición de herencia, debe obtener la anulación del testamento. Vid GAudet (1995) p. 301.

19 La anécdota es comentada por Zimmermann quien relata: "after a lengthy historical exposition, Van den Heever J was driven to the conclusion that, in dealing with nullity ipso iure and seeking to attribute substantive signifcance to the distinction between to voidability and nullity of legal acts, the commentators of the ius commune "were like blind men looking in a dark room for a black cat wich wasn't there". Cfr. Zimmermann (1996) p. 678. 
Con esta finalidad proponen diversos criterios: (i) la apariencia; (ii) el interés protegido y (iii) la substancia y efecto ${ }^{20}$. Sustancialmente, estas distinciones se condicen con la moderna contraposición entre inexistencia y nulidad.

Quienes fundan la diferencia en la sustancia y efectos, proponen la distinción entre dos tipos de requisitos del acto y, por consiguiente, dos géneros de ineficacia: aquella en virtud de la cual el acto simplemente no nace a la vida jurídica (nulidad radical) y aquella en virtud de la cual el acto puede ser privado de eficacia (anulabilidad) ${ }^{21}$.

Por su parte, la justificación en base al interés -atribuida a Bartolo- sostiene que los dos tipos de ineficacia se diferencian por el interés que protege la norma violada. Las ineficacias que resultan de la violación de una condición de validez establecida en atención al interés general son verdaderas nulidades, operan de pleno derecho y ab initio, y pueden ser invocadas por cualquier interesado y en cualquier tiempo. Por el contrario, si la regla violada mira a proteger ciertos intereses particulares, la ineficacia constituye una anulabilidad, ello significa que solo tiene lugar en virtud de la demanda impetrada por la parte a quien la ley pretende proteger ${ }^{22}$.

Con matices, esas concepciones se traspasaron al llamado ancien droit, donde fueron acuñadas las expresiones nulidad absoluta por oposición a nulidad respectiva (que luego asumiría el nombre de relativa), dependiendo del interés afectado era general o particular, y actos nulos por oposición a actos rescindibles, dependiendo de si la eficacia operaba $a b$ initio o mediante carta de rescisión ${ }^{23}$.

Atendida su importancia en el proceso de codificación francés, en este panorama resulta útil reseñar la opinión de DOMAT y POTHIER en la materia ${ }^{24}$, pues, aunque no fueron citados por A. BELLO en la parte respectiva, sus dichos son útiles para comprender algunas de las decisiones adoptadas por el legislador.

Para Domat, la nulidad se refiere a un defecto originario de la convención y, por tanto, equivale a su inexistencia ("falta de subsistencia"). Este autor no distingue entre diferentes clases de "nulidad", para él la nulidad es una sola y se contrapone a la "resolución", que afecta a convenciones en principio válidas y subsistentes ${ }^{25}$. Como causales de nulidad,

\footnotetext{
20 Vid KLEIN (2010) pp. 43 ss.

21 Gaudet (1995) p. 302; Coing (1996) t. I, p. 525.

22 Gaudet (1995) p. 302.

23 Gaudet (1995) p. 303 ss. Así, para D’Argentré, Coquille, Dumoulin y más tarde Boujorn, existen dos especies de ineficacias: la nullité, que opera de pleno derecho, y otra que solo da lugar a rescisión y, por tanto, debe solicitarse su declaración. Según explica de D’Argentrè, la justificación de esta diferencia radicaría en el carácter público o privado del interés involucrado en cada causal de ineficacia. Vid KLeIN (2010) pp. 85 ss.

24 En la preparación de este trabajo se han tenido a la vista las siguientes ediciones: Domat, Jean (1844): Las leyes civiles en su orden natural (trad. castellana de Felio Covarrubias y José Sardá, Barcelona, Imprenta de José Taulo, segunda edición); PОтHIER, Robert Joseph (2007): Tratado de las obligaciones (trad. castellana de Guillermo Cabanellas de Torres, Buenos Aires, Heliasta). Para facilitar su confrontación, las citas a estas obras se harán con referencia al número de párrafos y/o títulos, no de páginas. Un análisis de la distinción entre rescisión y nulidad en la obra de estos dos autores, puede verse en KLEIN (2010) pp. 87 ss.

25 "La nulidad y la resolución se diferencian en que cuando existe la primera solo ha habido una apariencia de convención, al paso que la última no hace más que destruir las que al principio eran válidas y subsistentes”. DOMAT, $1^{\text {a }}$ parte, lib. I, tit. I, secc, VI.
} 
DOMAT enumera todas que actualmente conocemos como $\operatorname{tal}^{26}$, incluidos el $\operatorname{error}^{27}$ y la incapacidad absoluta y relativa ${ }^{28}$. La única causal actual de nulidad que indica como causal de resolución es el dolo, pero señala que cuando se prueba el fraude, las convenciones "quedan resueltas y anuladas" 29 . En esta idea se encuentra un atisbo de la distinción entre nulidad y anulabilidad en la doctrina de DOMAT.

Otro aspecto destacable en la doctrina de DOMAT es el alcance que le otorga al carácter originario de la nulidad, pues reconoce que esto no se opone a la necesidad de una sentencia judicial en los casos en que la convención, "aunque nula, ha tenido alguna consecuencia" ${ }^{30}$. Desde ya ponemos el acento en esta reflexión, pues concuerda plenamente con la disposición del artículo 1.687 C.C.

En cuanto a POTHIER, la distinción básica propuesta por este autor es la contraposición entre nulidad y rescisión. La nulidad opera de pleno derecho, pues del acto nulo "no puede nacer acción alguna" 31 , y puede siempre pedirse. La rescisión debe ser solicitada por la parte correspondiente en el plazo de 10 años, que se computa dependiendo de la causal invocada $^{32}$. Según se aprecia de sus dichos, para formular esa clasificación, POTHIER atiende a dos criterios: (i) la distinción entre elementos esenciales y no esenciales del contrato; y (ii) el interés protegido por la norma.

Según este autor, "la falta de una de las cosas que son de la esencia del contrato impide que exista clase alguna de contrato; algunas veces esa falta cambia la naturaleza del contrato" 33 . En consecuencia, en caso de ausencia de consentimiento debido a error (de cualquier tipo, siempre que sea jurídicamente relevante) el acto es nulo, es decir no ha habido absolutamente contrato ${ }^{34}$. Por el contrario, en caso de fuerza o dolo, el consentimiento, y por tanto el contrato existe, pero el afectado o sus herederos o cesionarios "pueden hacerlo anular y rescindir, obteniendo al efecto órdenes de rescisión” ${ }^{35}$. El recurso a los elementos esenciales justifica que el acto sea también nulo cuando carece de causa ${ }^{36}$. Empero,

\footnotetext{
${ }^{26}$ Esta se encuentra resumida a propósito de la venta, donde señala que "las ventas nulas son aquellas que en ningún caso han tenido subsistencia, sea a causa de la incapacidad de uno de los contratantes, o bien porque la cosa vendida está fuera del comercio, o por algún vicio del contrato como si es contrario a las leyes y buenas costumbres, o por otra falta como si la venta dependía de una condición que no se ha verificado". Cfr. DOMAT, $1^{\text {a }}$ parte, lib. I, tit. II, secc, VIII.

27 Domat, $1^{\text {a }}$ parte, lib. I, tit. I, secc, V, $\$ 10$.

28 Domat, $1^{\text {a }}$ parte, lib. I, tit. I, secc, V, $\$ \$ 7$ ss.

29 Domat, $1^{\text {a }}$ parte, lib. I, tit. I, secc, VI, $\$ 8$.

30 "Si una convención, aunque nula, ha tenido alguna consecuencia, los contrayentes deben ser repuestos en el estado que tenían antes de celebrarla, en cuanto las circunstancias lo permitan, y con las restituciones que puedan tener lugar contra aquel que se halle responsable// Aun cuando exista esta nulidad no puede aquel que la reclama reponerse por sí mismo en sus derechos, si el otro no lo consiente; es necesario que recurra a la autoridad del juez para que falle sobre el negocio y restablezca a cada uno en su derecho (...)”. Cfr. Domat $1^{\text {a }}$ parte, lib. $1^{\circ}$, tit. V, $\$ \$ 15$ y 16 .

31 Cfr. Pothier (2007) $\$ 43$.

32 Véase, Pothier (2007) \$\$ 21 y 29, pp. 23 ss.

33 Pothier (2007) $\$ 6$.

34 Véase Pothier (2007) \$\$ 17-21.

35 Cfr. Pothier (2007) \$21, véase también $\$ 29$.

36 Pothier (2007) $\$ 42$.
} 
para Pothier el acto es también nulo "cuando la causa por la cual el compromiso ha sido contratado es una causa que hiere la justicia, la buena fe, o las buenas costumbres" ${ }^{37}$. Es decir, hay también nulidad cuando se atenta contra una regla de interés general, de ahí que la causa ilícita sea causal de nulidad y no de rescisión. Como veremos, este último antecedente resulta clave para la comprensión del artículo 1.682 del Código Civil.

\section{B. El tratamiento de la nulidad en el Código Civil francés}

El auge de la discusión en torno a la inexistencia jurídica en Chile fue producto del amplio debate que la doctrina francesa del s. XIX sostuvo en torno al argumento, y al tratamiento original que A. BELLo dio a la nulidad en el Código Civil ${ }^{38}$. En consecuencia, son necesarias algunas referencias a la nulidad al interior del Código Civil francés.

El Código francés no contiene un tratamiento sistemático de la nulidad ${ }^{39}$, sino que la trata de forma inorgánica en los artículos 1.117, 1.304 y 1.338. La primera de estas disposiciones, apartándose parcialmente de lo enseñado por POTHIER, sostiene que "la convención celebrada con error, fuerza o dolo no es nula de pleno derecho, ella solo concede una acción de nulidad o rescisión". Como se aprecia, hay aquí una distinción entre nulidad de pleno derecho (ab initio) y nulidad que opera trámite acción. A esta idea se suma lo dispuesto en el artículo 1.304, cuyo texto original señalaba: "en todos los casos en que la acción de nulidad o de rescisión de una convención no haya sido limitada a un tiempo menor por una ley particular, esta acción durará diez años” ${ }^{\$ 0}$. En consecuencia, la acción de nulidad dura 10 años, pero la nulidad de pleno derecho, por su misma naturaleza, no pareciera estar sujeta a ese plazo. Finalmente, el artículo 1.338 alude a la confirmación o ratificación de una obligación contra la cual la ley admite la acción de nulidad o rescisión, de aquí los autores franceses dedujeron que en los casos de nulidad de pleno derecho no es admisible la confirmación o ratificación.

Ante ese panorama legislativo, los autores franceses se preguntaban en qué casos operaba la nulidad de pleno derecho y en qué casos (además del error, fuerza y dolo) había lugar a acción de nulidad, intentando, además, encontrar una justificación para esta distinción. En este intento se ensayan diversas posibilidades. Algunos distinguen entre nulidad ipso iure y rescisión, señalando que la diferencia entre ellas radica en la apariencia, la nulidad sería procedente en caso de un vicio extrínseco y aparente; por el contrario, cuando el acto tiene apariencia de validez, solo procede la rescisión. Otros, recurren a la noción de interés público versus interés privado ${ }^{41}$.

37 Pothier (2007) \$ 43.

38 Como describe Alcalde, durante la primera mitad del s. XX se en produjo en Chile una fuerte influencia de la doctrina francesa, "que conllevará una trasposición de las explicaciones de la nulidad en el sistema del Code Civil a la disciplina que de ella hace el Código chileno, sin reparar en las diferencias históricas y de tratamiento que en cada uno de ellos se observan". Cfr. Alcalde (2010) p. 70.

39 Esta es una característica compartida de las primeras codificaciones modernas, influenciadas por el escaso desarrollo sistemático que había alcanzado la institución en los siglos precedentes. Vid CoING (1996) t. II, pp. 552 ss.

40 Actualmente el plazo es de cinco años.

41 Por todos, vid Gaudet (1995) pp. 308 ss. 
Para efectos de este trabajo tiene especial importancia la opinión de DeLvincourT, pues su obra inspiró el tratamiento de A. BELlo dio a la nulidad ${ }^{42}$. Tal autor, teniendo en mente las enseñanzas del Derecho precodificado, distingue entre dos especies de nulidad: (i) nulidad de interés público y (ii) nulidad de interés privado o rescisión. La primera, es absoluta, se refiere a un vicio radical y, por lo mismo, puede ser solicitada por cualquiera que tenga interés en ella, incluido el Ministerio Público, no se sanea por el paso del tiempo y no admite ratificación por las partes. La segunda, es relativa, solo puede ser invocada por aquellos en cuyo interés ha sido establecida, se sanea por el paso del tiempo y admite ratificación por las partes ${ }^{43}$. Con todo, Delvincourt afirmaba que la imposibilidad de saneamiento de la nulidad absoluta no afectaba la prescripción de la acción para solicitarla, pues, en su opinión, el plazo de 10 años que el artículo 1.304 del Código francés estableció para solicitar la nulidad se aplicaba de manera general tanto a la nulidad absoluta como relati$v^{44}$. No es difícil ver aquí una estrecha relación entre esta forma de concebir la nulidad y su regulación en el Código Civil chileno, con la diferencia que en este último se establecieron plazos diferenciados de saneamiento.

\section{El Surgimiento de la teoría de la ineXistencia}

En ese escenario, y muy cercana a la codificación, se inserta la famosa obra de ZACHARIÆ Handbuch des franzosischen Zivilrechts $(1808)^{45}$, en la cual surge la teoría de la inexistencia como un tercer género, diferente de la nulidad y la rescisión. Para ZaCHARIAE el acto jurídico requiere de ciertos elementos esenciales para tener una existencia fáctica y, además, cumplir con las solemnidades necesarias para tener una existencia jurídica ${ }^{46}$. Sin estos elementos esenciales el acto jurídico no puede absolutamente concebirse y es, por tanto, inexistente.

Así descrita, la inexistencia propuesta por ZACHARIAE coincide con la nulidad propuesta por Pothier; sin embargo, para ZACHARIAE - salvo el caso de falta de solemnidades- la inexistencia se refiere a una cuestión fáctica, la ausencia material de algún elemento esencial (consentimiento, objeto, etc. ${ }^{47}$, mientras que la nulidad de PoTHIER opera también en casos de ausencia jurídica. De ahí se sigue que para POTHIER tanto la ausencia de

\footnotetext{
42 Vid infra, apartado III A.

43 Delvincourt (1834) p. 181.

44 Delvincourt (1834) p. 589.

45 En la preparación de este trabajo se ha tenido a la vista la segunda edición de la traducción al francés: ZaChariae, M. C. S (1843-1846): Cours de droit civil français. Revu et augmenté, avec l'agrément de l'auteur par MM. C. AUbrY et C. RAU (Strasbourg, F. Lagier, segunda edición).

46 "L'acte inexistaant est celui qui ne réunit pas les conditions essentielles à son existence de fait d'après les notions du droit philosophique, ou qui n'a pas été accompagné des solennites indispensables pour lui donner une existence juridique d'apres l'espirit du droit positif'. Cfr. ZACHARIAE (1843-1846) p. 66.

47 Zachariae no individualiza las condiciones esenciales para la existencia fáctica del acto, se limita a señalar que es un gran problema que no puede tener una regla general y que, además, el ordenamiento jurídico puede transformar una condición fáctica en una condición jurídica. Esto último, señala, ha ocurrido con el error, pues el consentimiento dado por error es de hecho inexistente, sin embargo, el Código Civil ha establecido que el acto es simplemente anulable. Cfr. ZaChariae (1843-1846) p. 66.
} 
causa, como la causa ilícita, conllevan la misma consecuencia ${ }^{48}$. Para ZACHARIAE, en cambio, en caso de causa ilícita el acto existe, pero es vicioso y, por tanto, adolece de nulidad ${ }^{49}$.

En síntesis, para ZaCHARIAE la falta de eficacia de un acto puede provenir de su inexistencia, de su nulidad ipso iure o bien de su anulabilidad o rescisión. La diferencia entre la primera y las otras dos radicaría en que estas últimas necesitan de un pronunciamiento judicial que las declare, mientras que la primera no. De esta forma, para ZACHARIAE, tanto la nulidad ipso iure (llamada también nulidad radical) como la rescisión necesitan de una sentencia judicial, y divide las causales de ineficacia en causas fácticas y jurídicas. Las causas fácticas (ausencia material de un elemento esencial o ausencia de la solemnidad) conllevan inexistencia. Las causas jurídicas producen la nulidad del acto, el cual puede ser nulo o anulable ${ }^{50}$, pero en cualquier caso necesita sentencia judicial que la declare.

ZaChariae cierra su análisis con la confirmación del acto. Señala que para que esta opere es necesario que el acto exista, pues no pueden confirmarse las obligaciones naturales ni los actos inexistentes. Por el contrario, los actos anulables pueden siempre confirmarse, salvo que se trate de un vicio de orden público (ejemplo, causa ilícita) o de la falta de formalidades en la donación entre vivos ${ }^{51}$, pues en estos casos las partes no pueden con su simple voluntad sanear el vicio.

\section{Superación de la teoría de la inexistencia en el Derecho francés}

Las ideas de ZACHARIAE tendrán gran resonancia en la doctrina y jurisprudencia francesa del s. XIX, especialmente a propósito de la máxima no hay nulidad sin texto y, en particular, a la ausencia de una sanción para los matrimonios celebrados entre personas del mismo sexo $^{52}$. Sin embargo, la tripartición establecida por ZACHARIAE dará paso a una bipartición entre inexistencia y anulabilidad o simplemente nulidad.

Según esta bipartición: en caso de inexistencia el acto no nace, por consiguiente: (i) opera ipso iure, sin que haya necesidad de pronunciamiento judicial, en caso de litigio, el juez solo debe constatar la inexistencia; (ii) puede ser invocada por cualquier persona que tenga interés, incluso ser declarada de oficio por el tribunal; y (iii) están excluidas la prescripción y la confirmación, pues ellas significarían dar vida a algo que no existe ${ }^{53}$. Por su

\footnotetext{
48 Gaudet (1995) p. 312.

49 Véase Zachariae (1843-1846) p. 68.

50 BOUdot (2009) p. 85.

51 Zachariae (1843-1846) p. 453.

52 Planiol (1903) p. 114; De Castro y Bravo (1985) pp. 462 ss.; Cifuentes (1986) p. 580; Philippi (2009) p. 352; Baraona (2012) p. 33; Domínguez (2012) p. 175.

53 Esta idea proviene de una aceptación de la máxima contenida en D.50.17.29. Un resumen de esta doctrina puede verse en RENARD y VieujeAn (1962) pp. 245 ss. Una situación semejante se produjo en el Derecho español, que al igual que el francés contempla solo un plazo de prescripción de la acción de nulidad y no distingue expresamente entre nulidad absoluta y relativa. Véase De Castro y Bravo (1985) p. 466. Por lo demás, se trataba de una idea generalizada en el Derecho precodificado; por ejemplo, el $\$ 108$ del Primer Proyecto de Código Civil alemán establecía "Un negocio jurídico nulo se le considera como no celebrado en cuanto a los efectos jurídicos deseados”. La disposición fue suprimida por considerársela innecesaria. Al respecto se dijo que "el concepto de negocio nulo está determinado en la ciencia y por ello no precisa una definición detallada". Flume (1998) p. 643.
} 
parte, el acto anulable produce los mismos efectos que el acto jurídico válido mientras su nulidad no haya sido declarada, en consecuencia: (i) la ineficacia es una consecuencia de la sentencia de anulación dictada por el juez; (ii) la anulación puede ser provocada exclusivamente por las personas a cuyo favor la anulabilidad ha sido establecida; y (iii) el derecho a provocar la anulación se extingue por la consolidación del acto, que puede operar mediante prescripción o confirmación.

La doctrina francesa no tardó en advertir que la forma que finalmente adoptó la inexistencia como causal de ineficacia se condice con la antigua nulidad absoluta de los autores franceses o simplemente nulidad de los romanos y de PoTHIER, de ahí que terminara por identificarlas, dando lugar a lo que se conoce como la "doctrina clásica de la nulidad" 54 . Esta doctrina fue durante cuestionada, señalando que lo verdaderamente importante no es determinar si el acto existe o no, sino si los efectos que haya generado pueden ser atacados, dando paso a una concepción procesalista de la nulidad que la considera un "derecho a crítica" ${ }^{55}$. En conclusión, la doctrina clásica de la nulidad, y con ello la idea de inexistencia, fue abandonada ${ }^{56}$. Se impuso la distinción entre nulidad absoluta y relativa, dependiendo del interés protegido y, por consiguiente, de quien tiene derecho a invocarla ${ }^{57}$ : (i) si se trata de una norma impuesta en razón del interés general, la nulidad es absoluta y puede invocarla cualquier interesado e incluso declararse de oficio; (ii) si la norma ha sido impuesta en consideración del interés privado, la nulidad es relativa y solo puede invocarla el beneficiario. Atendido que deriva de una norma de interés general (en Chile diríamos de orden público) el acto de adolece de nulidad absoluta no puede ser objeto de confirmación por la partes, pero la acción nulidad absoluta sí está sujeta a prescripción, exigiéndose el plazo más largo previsto por el Código.

\section{E. LA TEORÍA DE LA INEXISTENCIA EN EL PANORAMA NACIONAL}

En Chile, la discusión en torno a la inexistencia tiene larga data ${ }^{58}$. En resumen, sus partidarios sostienen que el Código concibe la nulidad como sanción a la omisión de un requisito establecido "para el valor" del acto (art. 1.681), es decir, para su validez, sin referirse a la existencia del acto. Por eso, la consecuencia jurídica de la falta de un requisito de existencia del acto sería precisamente la inexistencia ${ }^{59}$. Agregan que, porque el acto inexistente

\footnotetext{
54 Vid Thibierge (2010) pp. 329 ss.

55 Jаріот (1909), passim, especialmente p. 285. Según esta doctrina, la nulidad consiste esencialmente en el derecho que tienen ciertas personas de criticar la validez del acto, su carácter absoluto o relativo depende de quién tiene este derecho. Una exposición crítica de esta doctrina puede verse en ThiBIERGE (2010) pp. 335 ss.

56 Ghestin (1988) p. 995. El rechazo a la inexistencia es generalizado en la doctrina francesa, aunque con algunas precisiones y excepciones, por todos, vid ThIBIERGE (2010) pp. 333 ss.

57 Esta es la única distinción actualmente aceptada. Por lo mismo, en el Anteproyecto de Reforma al Código Civil se estableció que la ausencia de consentimiento, la falta de objeto y la falta de causa, conllevan nulidad relativa. Por el contrario, la causa ilícita o el objeto ilícito, conllevan nulidad absoluta. Véase Ante-Proyecto de Reforma del Código Civil francés, artículos 1.109-2, 1.122 y 1.124. Una traducción al castellano de estos artículos puede consultarse en Hinestrosa (2006), passim.

58 Para una exposición detallada de esta discusión vid doctrina citada en nota 1, especialmente RodríGUEZ GreZ (1995) pp. 68 ss.

59 Lecaros (1997) P. 1.
} 
no produce efecto alguno, el Código ni siquiera previó la inexistencia como modo de extinguir las obligaciones, a diferencia de la nulidad ${ }^{60}$. Este planteamiento se apoya en el tenor literal de algunas normas que, mediante el empleo de expresiones como "se mirará como no escrito" o "no producirá efecto alguno", establecerían una ineficacia ab initio de ciertos actos jurídicos ${ }^{61}$. Finalmente, sostienen que el Código no regula la inexistencia porque "lo que no existe en la naturaleza no puede ser regulado normativamente" ${ }^{62}$. En cuanto a sus efectos, se dice que a la inexistencia no se aplica el plazo de saneamiento del artículo 1.683 C.C., pues la nada no puede sanearse y tampoco es necesaria una sentencia judicial que la declare, pues opera ipso iure $e^{63}$.

Por su parte, para negar que la inexistencia tenga acogida en el Código Civil se recurre principalmente a su falta de regulación, pues solo reguló la nulidad (dividiéndola en absoluta y relativa $)^{64}$. En cuanto al fondo, se discute sobre todo las consecuencias de la inexistencia. La supuesta operatividad ipso iure de la inexistencia se mostraría poco práctica, pues en caso de duda siempre será necesaria una declaración judicial ${ }^{65}$. Por otra parte, su carácter imprescriptible perturbaría gravemente la seguridad jurídica, principio general que exige consolidar las situaciones jurídicas con el paso del tiempo.

Las fluctuaciones doctrinarias se han visto reflejadas en la jurisprudencia, que también es contradictoria en cuanto a la recepción de la inexistencia en Derecho interno: mientras varios fallos han descartado categóricamente que la inexistencia tenga cabida en Chile $^{66}$, otros han dicho lo contrario ${ }^{67}$. Sin embargo, el análisis de la jurisprudencia eviden-

60 Claro Solar (1979) p. 581.

61 Claro Solar (1979) pp. 581 ss.; Vodanovic (1945) pp. 514 ss.; Lecaros (1997) pp. 3 ss.; Ducci (1988) pp. 311 ss.; Vial Del Río (2003) pp. 237 ss.

62 Rodríguez Grez (1995) p. 32. Este autor concluye su razonamiento sosteniendo que "la inexistencia es irregulable jurídicamente desde una doble perspectiva. Primero, porque el negocio no se ha completado, hipótesis necesaria para el surgimiento de los efectos; y segundo, porque la ausencia de efectos paraliza la reglamentación normativa. Esta última carece de objeto y fin. Así las cosas, la inexistencia solo interesa en la medida en que la ley le asigne efectos a un elemento aislado concurrente o califique una apariencia en función de intereses de terceros”. Cfr. Rodríguez Grez, p. 33.

63 Por todos, vid Vial del Río (2003) pp. 237 ss.; Domínguez (2012) p. 179.

64 Vial del Río (2003) pp. 237 ss.; Domínguez (2012) p. 179.

65 Domínguez (2012) p. 179.

66 La Corte Suprema señala que la máxima sanción de ineficacia que nuestro sistema recoge es la nulidad absoluta. "Entre nosotros es claro -y bastante obvio- que nuestro derecho nacional no consulta una alusión expresa y sistémica de la inexistencia, ya no como sanción sino como la consecuencia negativa y máxima secuela jurídica de la ineficacia de los actos defectuosos, por lo que, en general, se acepta su asimilación a la máxima sanción que nuestra normativa prevé: la nulidad absoluta". Mansoor con De la Barrera (2011). En el mismo sentido: Llona con Carmona (1931); Geisse con Murúa (1942); Agrícola Pecuaria S.A. con Agrícola Super Limitada (2012); Muñoz con Ramos y otra (1966); Marchant con Cancino (1985); Carrasco con Banco Unido de Fomento (1990); Jaras con Universidad de Chile (1997).

${ }^{67}$ En este sentido se ha dicho que "no se trata en consecuencia [...] de una eventual nulidad, susceptible de sanearse por el transcurso de tiempo. Es efectivo que el art. 1.683 del Código Civil dispone que la nulidad absoluta no puede sanearse ni por un lapso de tiempo que no pase de diez años. Pero ella supone un acto que adolece de una causal de nulidad absoluta y no -como en el caso de autos- de un acto que no reúne las condiciones necesarias para existir legalmente”. Banco del Estado de Chile con Sauterel (1991). En el mismo sentido: Torres con Fisco (1945); Román con Maturana (1914); Correa con Correa (1922); Selman D., Pedro (Recurso de queja) 
cia que los pronunciamientos que han admitido la inexistencia lo han hecho más bien con carácter retórico o como sinónimo de nulidad absoluta ${ }^{68}$. En la práctica, la invocación de la inexistencia no conduce a soluciones diferentes de aquellas a que llevaría la nulidad absolu$\mathrm{ta}^{69}$, por ejemplo en cuanto a plazos de prescripción o a protección de la apariencia. Así, en la escasa jurisprudencia reciente que se ha referido a la materia, se ha estimado que la constatación de la inexistencia de un acto no permite ignorar los efectos que de hecho él haya producido, y por tanto, subsisten las enajenaciones subsiguientes efectuadas a terceros ${ }^{70}$. Se ha negado lugar a la acción de inexistencia, fundándose en que el demandante debió haber demandado directamente la restitución del bien, pero se acogió la demanda subsidiaria de nulidad absoluta ${ }^{71}$. Se han extendido a la inexistencia las reglas de la nulidad absoluta en relación con una acción reivindicatoria ${ }^{72}$. Incluso se ha fallado que las acciones de inexistencia y de nulidad absoluta prescriben en cinco años, en conformidad con las reglas generales de prescripción de las acciones ordinarias ${ }^{73}$.

(1967); Ríos CON NAUDON (1936); SÁNCHEZ CON VALENZUELA (1945); GUAJARDO CON CAMPOS (1981); SOCIEDAD

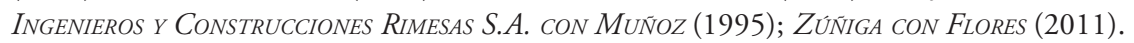

68 En este sentido la Corte Suprema ha reconocido que "la única cuestión fundamental del debate en la parte que se estudia, es la nulidad absoluta. Debe observarse a este respecto, que la doctrina jurídica hace diferencias entre dicha nulidad y la inexistencia de un acto jurídico, para concluir que la falta de voluntad, que se denomina consentimiento en los actos bilaterales, produce esta y no aquélla: pero en el Código Civil se confunden ambos efectos de la carencia de requisitos de existencia y de validez, de manera que no hay inconveniente para denominar nulidad absoluta a la inexistencia”. ROMERO Y OTRO CON CORTÉS Y OTRO (1954). En el mismo sentido: Banco Alemán Transatlántico con Banco Estado de Chile (1964).

69 La Corte Suprema ha señalado que "la ineficacia del contrato, sea por inexistencia o por la declaración de nulidad absoluta es prácticamente equivalente, pues en ambos casos se supone que el contrato nunca existió ni llegó a producir efecto alguno, por lo que la sentencia que rechazó la demanda y que declaró la inexistencia produce los mismos efectos que si hubiera rechazado la demanda declarando la nulidad absoluta del contrato". Agricola Pecuaria S.A. con Agrícola Super Limitada (2012).

70 Castro con Espinoza (2010). Literalmente señaló: "la inexistencia constatada no puede afectar a derechos que se han constituido a favor de terceros, quienes no han sido parte de este juicio y respecto de quienes no se ha acreditado mala fe".

71 González Freire Wynnifred con Doneaud Catalán María Eliana (2013). La Corte de Santiago sostuvo: "este Tribunal de Alzada, es de la opinión que no es dable demandar de "inexistencia”, pues esta causal de ineficacia jurídica no otorga acción que pueda sustentarse a través de una "demanda de inexistencia", dado que de la "nada" no nace acción alguna que pueda hacerse valer, por lo cual, la acción que debió intentar la actora es una restitutoria, ya sea en virtud de una tenencia de precario u otro título precario, previa constatación judicial de la inexistencia, motivo por el cual, en lo resolutivo no se hará lugar a ella. $/ / 15^{\circ}$ ) Que, sin perjuicio de lo razonado, esta Corte estima que en la especie ha de proceder la declaración de nulidad absoluta, pues como ha quedado claramente establecido, en la dación en pago, cuya nulidad pide la demandante, en calidad de heredera de doña Julia González Freire, no se han unido las “voluntades en el consentimiento" que la ley exige como requisito de validez, dada su naturaleza, tal como lo refiere el artículo 1.682 inciso primero del Código Civil, al señalar como causal de nulidad absoluta, la "omisión de algún requisito que las leyes prescriban para el valor de ciertos actos o contratos en consideración a su naturaleza”, siendo el artículo 1.445 No 2 del mismo código, el que exige tal requisito, consentimiento que además, debió otorgarse por escritura pública según ya se ha referido, configurándose como segunda causal de nulidad absoluta a su turno, la omisión de alguna "formalidad" (artículo 1.682 inciso $\left.1^{\circ}\right)(\ldots)$ ".

72 ZÚNIGA CON FLORES (2011).

73 WEISSENBERG Y OTRO CON KUBORN Y OTRO (2009). 
F. EQUiVALENCIA SUSTANCIAL ENTRE LOS CONCEPTOS NULIDAD, NULIDAD ABSOLUTA, NULIDAD DE PLENO DERECHO, NULIDAD RADICAL USADOS EN ESPAÑA E ITALIA CON LA NOCIÓN DE INEXISTENCIA DE LA DOCTRINA NACIONAL

Dados (i) el común origen de las disposiciones, (ii) la semejanza de la problemática y (iii) el frecuente uso de su literatura por la doctrina nacional, resulta relevante señalar lo que ha ocurrido en España e Italia en relación con la nomenclatura alusiva a la nulidad del acto jurídico y a los intentos por distinguirla de la inexistencia. Antes que todo, cabe recordar que en estos países la distinción entre nulidad absoluta y relativa corresponde a la distinción entre nulidad y anulabilidad del acto jurídico ${ }^{74}$, respectivamente. Sin embargo, también se utilizan los términos nulidad radical o de pleno derecho e inexistencia, para indicar la nulidad absoluta del acto $^{75}$. A diferencia de lo que ha ocurrido en Francia, el rasgo más sobresaliente de esta especie de nulidad es el carácter meramente declarativo y, por tanto, imprescriptible de la acción judicial para constatarla, fundado en que el acto que no ha llegado a surgir a la vida del Derecho y, por tanto, no puede consolidarse por el simple paso del tiempo ${ }^{76}$.

Así, en la doctrina española hay quien afirma que "la nulidad de pleno derecho o nulidad radical opera cuando faltan y no tienen existencia alguno de los elementos esenciales del contrato (...), o cuando se infringe algún precepto legal prohibitivo (...). La nulidad relativa o anulabilidad, en cambio, tiene lugar, (...) cuando, concurriendo dichos requisitos, afloran vicios que invalidan el contrato con arreglo a la ley. La diferencia no es baladí, puesto que en el primer caso la acción es imprescriptible (supuesto de nulidad radical o inexistencia del contrato), resultando el negocio insubsanable, de tal suerte que la declaración de nulidad produce efectos ex nunc (sic), o sea con efecto retroactivo, pudiendo además ser declarada de oficio por el juez"77. Como se aprecia, esta noción de nulidad corresponde sustancialmente a lo que la doctrina nacional llama inexistencia. Esta idea es compartida por BARAONA, para quien, en Chile, "la configuración jurídica de la inexistencia

\footnotetext{
${ }_{74}$ La terminología empleada para referirse a la nulidad varía de un ordenamiento a otro. Un resumen sobre la terminología y su contenido sustancial en diferentes ordenamientos puede consultarse en: FAUVARQUE-CosSON Y Mazeaud (2008) pp. 320 ss.; Ramón (2012) pp. 63 ss.

${ }^{75}$ En este sentido, a propósito del artículo 6.3 del Código Civil español que sanciona a los actos prohibidos con nulidad de pleno derecho, la doctrina española señala que dicho artículo alude a la nulidad absoluta de los actos. Aclarando que "la declaración de nulidad absoluta del acto jurídico va a significar la privación de todos los efectos que el mismo esté llamado a producir; el acto se entiende como no realizado, como si nunca hubiera existido. La sentencia que declare la nulidad del acto es una sentencia declarativa. Los efectos se producen $e x$ tunc, desde la realización del acto infractor, puede ser alegada por cualquier interesado en un procedimiento judicial y no está sujeta al plazo de caducidad o prescripción para hacerla valer, incluso puede ser apreciada de oficio por el juez" (énfasis añadido). Cfr. CASADo (2006). En el mismo sentido se ha señalado que en España "la consecuencia general que anuda el Código Civil a la ilicitud de la causa, que engloba tanto los contratos ilegales como los inmorales, es la nulidad de pleno derecho o absoluta (arts. 6.3, 1.255 y 1.275)" (énfasis añadido). Cfr. INFANTE y Oliva (2009) p. 23. En la misma obra los autores emplean la expresión nulidad radical para referirse a la noción de nulidad de pleno derecho empleada en el artículo 6.3. Ídem, p. 24.

${ }^{76}$ En España esta es una conclusión doctrinaria y jurisprudencial, pero muy afianzada y con escasos detractores, por todos véase PASQuau Liaño (1997) passim; Pasquau Liaño (2006). En Italia, en cambio, la imprescriptibilidad ha sido expresamente establecida en el Código Civil, art. 1.422: "Imprescrittibilità dell'azione di nullità. L'azione per far dichiarare la nullità non è soggetta a prescizione. (...)”.

77 Cfr. Guerra (2003).
} 
es muy similar a lo que en Derecho comparado se conoce como el simple término de 'nulidad', 'nulidad absoluta', o 'nulidad radical'"78.

Lo dicho encuentra confirmación cuando se observa que en el Código Civil italiano, aquellas que la doctrina nacional reconoce como causales de inexistencia constituyen causales de nulidad. Tal es el caso de la falta de acuerdo, la falta de causa, la falta de objeto, la falta de solemnidades ${ }^{79}$. Asimismo, en España Federico de Castro afirma que en un sentido amplio la nulidad absoluta comprende: al negocio inexistente, al negocio imperfecto y al prohibido ${ }^{80}$.

A fin de evitar confusiones, no pueden dejar de mencionarse los esfuerzos de alguna doctrina italiana y española orden a distinguir entre nulidad absoluta (y sus sinónimos) e inexistencia ${ }^{81}$. Sin embargo, atendidas las comunes consecuencias jurídicas de ambas instituciones, no existe consenso en torno a en qué radicaría exactamente la diferencia ${ }^{82}$ :

i. Al igual que algunos autores antiguos, hay quienes afirman que la diferencia radica la apariencia de acto $^{83}$. En consecuencia, correspondería hablar de inexistencia cuando falta una situación socialmente calificable de contrato $^{84}$. Le falta aquel mínimo esencial que permite hablar de un acontecimiento contractual ${ }^{85}$. Esta con-

\footnotetext{
78 Cfr. Baraona (2012) p. 36. Así se justifica que el mismo Betti, defensor de la inexistencia como una hipótesis de ineficacia diferente de la nulidad, afirme que "è nullo il negozio che per deficienza di qualche elemento essenziale rispondente alla configurazione richiesta, sia inidoneo a dar vita a quella nuova situazione giuridica che il diritto ricollega al rispettivo tipo legale in conformità con la funzione economico-sociale sua caratteristica". Cfr. BЕTTI (2002) p. 462.

79 Vid C.C. italiano arts. 1.325 y 1.418. Vid el comentario al artículo 1.418 en GaLgano et al. (1998) pp. 78 ss.

80 De Castro y Bravo (1985) p. 472.

81 Las distintas posiciones de la doctrina italiana y española, con adición de la peruana, pueden verse en MorALES (2005) passim. Específicamente en relación a la doctrina italiana: TOMMASINI (1972) p. 871 ss.

82 En este sentido en España se ha dicho que "en ocasiones, la doctrina y la jurisprudencia, se refieren a la "inexistencia" del contrato diferenciándola de la nulidad absoluta, para indicar aquellos supuestos en que al contrato le faltan los elementos esenciales para recibir esa calificación (...). En nuestro ordenamiento es difícil distinguir entre inexistencia y nulidad absoluta, ya que produce las mismas consecuencias”. Cfr. PARra (2010). En el mismo sentido DELGADO y LUCÁN (2005) p. 43 ss. Una situación similar se presenta en Italia, donde se ha dicho que "la distinzione tra nullità e inesistenza è ammessa dalla dottrina prevalente, che però incontra la difficoltà di precisare che cosa occorre affinché il negozio possa dirsi esistente". Cfr. BIANCA (2000) p. 616, n. 5.

83 Vid Atienza y Manero (2003) pp. 724 ss. La misma idea se encuentra en alguna doctrina argentina sobre la materia, vid Cifuentes (1986) pp. 582 ss. En el Derecho chileno esta idea ha sido ampliamente defendida por Baraona, quien postula que "la nulidad proviene de la insuficiencia del acto respecto de los requisitos legales para tener eficacia, la inexistencia de su falta de apariencia y materialidad jurídica”. Cfr. BARAONA (2012) pp. 38. La idea ya se encontraba en dos artículos del mismo autor publicados el año 2005, vid bibliografía citada.

84 BiANCA (2000) p. 616. Esta doctrina se remonta a la obra de Betti, quien defiende la diferencia entre nulidad e inexistencia señalando que "sono configurabili casi in cui può paralarsi di vera inesistenza giuridica del negozio che si è inteso fare, in quanto non esiste di esso che una vuota apparenza, che, se può aver ingenerato in qualcuno degli interessati l'impressione superficiale di averlo compiuto o de avervi assistito, non produce però assolutamente nessun effetto giuridico, neppure di carattere negativo o aberrante". Cfr. BETTI (2002) p. 461.

85 Galgano et al. (1998) p. 92; Galgano (2012) pp. 265. En ambas sedes este autor explica que la jurisprudencia italiana ha recurrido a la noción de inexistencia para invalidar ciertos acuerdos de asamblea que no cumplen con los requisitos mínimos, pero que ello obedece al hecho de que, aplicando las reglas legales, la sanción sería la anulabilidad del acto, lo que implica un breve tiempo de convalidación.
} 
cepción ha sido acogida en el anteproyecto de Código Europeo de Contratos de la Academia de Pavía ${ }^{86}$.

ii. Otros señalan que la diferencia radica en que la nulidad absoluta entraña un defecto de orden público y, por tanto, no admite ratificación por las partes; mientras que la inexistencia se refiere a la falta de un elemento para que el acto nazca y que, por lo mismo, puede ser suplido por voluntad de las partes completando el acto jurídico deficiente ${ }^{87}$.

iii. Finalmente, se ha dicho que la distinción entre nulidad e inexistencia se refiere a distintos planos de realidad. La inexistencia alude al plano fáctico, mientras que la nulidad alude al plano jurídico. En este sentido se dice que la nulidad, como sanción jurídica, presupone la existencia del acto, mientras que la inexistencia corresponde al plano estricto del supuesto de hecho ${ }^{88}$. Cabe destacar que esta concepción se condice con los postulados de la inexistencia según la doctrina de Zachariae ${ }^{89}$.

En síntesis, los intentos de la doctrina española e italiana por diferenciar la nulidad de la inexistencia difieren de los esfuerzos de la doctrina nacional, pues en tales países las características que en Chile se atribuyen a la inexistencia, especialmente el carácter meramente declarativo y, por tanto, imprescriptible de la acción, son atributos propios de la nulidad. Esta idea debe considerarse a la hora de valerse de dicha doctrina.

\section{EXCLUSIÓN SUSTANCIAL DE LA “INEXISTENCIA” EN EL CÓDIGO DE BELLO}

\section{A. Regulación sistemática de la nulidad en el Código de Bello}

En el Mensaje del Código Civil se asegura que, en su redacción, "sobre la nulidad y rescisión de los contratos y demás actos voluntarios que constituyen derechos, se ha seguido de cerca el código francés ilustrado por sus más hábiles expositores”. Sin embargo, la verdad es que A. BELLo se apartó en gran medida de la regulación francesa, estableciendo una sistematización mucho más precisa, que tiene como base la proporcionada por DeLviN-

\footnotetext{
86 "No existe contrato alguno en ausencia de un hecho, o de un acto, o de una declaración, o de una situación que pueda ser exteriormente reconocida y referida a la noción social de contrato”. Cfr. artículo 137.1, Código Europeo de Contratos, versión española disponible en http://www.accademiagiusprivatistieuropei.it/. Sobre los conceptos inexistencia, nulidad y anulabilidad en este cuerpo normativo, vid PARRA LuCÁN (2004) pp. 549 ss.; De Los Mozos (2005) passim.

87 En este sentido (citando a Antonio Manuel Morales Moreno) Ramón (2012) p. 82. Sin embargo, la misma autora indica que "en la actualidad la mayoría de nuestra doctrina aboga por considerar obsoleta dicha figura [de la inexistencia] y su supresión. En cuanto quedan definidas y distinguidas las categorías de nulidad, consideran que deja de tener sentido utilizar la figura de la inexistencia”. Ídem.

88 PASQUau Liaño (1997) p. 161 ss. En el mismo sentido en Italia se ha sostenido que "le varie proposte per fondare dogmáticamente la distinzione [entre nulidad e inexistencia] accusano un comune errore di base, dovuto alla confusione tra due diversi e inconfondibili piani della realtà: quello della realtà pregiuridica (naturalistica, sociológica) e quello della realtà giuridica (delle situazioni qualificate giuridicamente (...) ”. Cfr. TOMMASINI (1978) p. 871. 89 Vid supra, apartado II C.
} 
COURT. Así lo demuestran la nota al artículo 1.866 del Proyecto Inédito ${ }^{90}$ y la comparación de la sistemática del Código Civil con la obra de este autor ${ }^{91}$.

En concreto, mientras que el Código Civil francés se refiere de forma inorgánica al argumento, dando pie para que en la ciencia jurídica francesa se desarrollaran teorías muy diferentes ${ }^{92}$, el Código Civil chileno enuncia un concepto común de nulidad y luego distingue entre nulidad absoluta y relativa, estableciendo diferencias en cuanto a: (i) sus causales; (ii) quién puede alegarla; (iii) el plazo de saneamiento; y (iv) la ratificación de las partes.

\section{B. Decisión deliberada del A. Bello de apartarse del entendimiento TRADICIONAL EN LA MATERIA}

Entre los argumentos para señalar que la inexistencia no tiene cabida está el hecho de que el Código Civil solo reguló la nulidad (absoluta y relativa) y no se pronunció sobre la inexistencia. A este argumento se contesta que no era necesario que se contemplara la inexistencia, pues "los actos inexistentes, por lo mismo que no existen, no pueden ser reglamentados o legislados" mente porque no existe en la naturaleza ${ }^{94}$.

Sin embargo, la reconstrucción histórica demuestra que A. Bello conocía la equivalencia conceptual entre nulidad absoluta e inexistencia, especialmente en lo referido su carácter insanable e ipso iure, y deliberadamente decidió incluir la posibilidad de saneamiento por el paso del tiempo, innovando con respecto al tratamiento tradicional. De esta circunstancia dan cuenta diversos antecedentes:

i. A. BeLlo conocía perfectamente la máxima contenida en D.50.17.29, según la cual "quod initio vitiosum est non potest tractu temporis convalescere". En efecto, en sus Instituciones de Derecho Romano, a propósito del testamento, señala "esto es conforme a la regla Catoniana, según la cual la institución de heredero que hubiera sido inútil si el testador hubiera fallecido inmediatamente después de testar, no se hace válida por haber vivido más tiempo; lo que se conforma también con la regla general de derecho, que lo que en su origen es nulo, no adquiere valor con el tiempo" (énfasis añadido $)^{95}$.

ii. En el Mensaje del Código Civil se contrapone la rescisión a la nulidad ipso iure a propósito de los actos de los menores de edad. En tal sentido se señala "según estos códigos, el contrato celebrado por un menor sin el consentimiento de un guardador no es nulo ipso iure, aunque puede rescindirse".

\footnotetext{
90 Vid Bello (1981a) p. 559.

91 Este es el único autor que cita Bello en sus notas al Código Civil. Además, la semejanza textual entre lo sostenido por este autor y los artículos de la nulidad es evidente.

92 Coing (1996) t. I, p. 254.

93 Cfr. Philippi (2009) p. 353.

94 Rodríguez Grez (1995) pp. 32 ss.

95 Cfr. Bello (1981b) p. 89.
} 
iii. La fuente de inspiración directa en la regulación de la nulidad fue DelvincourT, quien señala que una de las características de la nulidad absoluta es que no se sanea por el paso del tiempo, ni por la ratificación de las partes ${ }^{96}$, aun cuando la acción para solicitarla sí prescribe ${ }^{97}$.

iv. En conformidad con sus fuentes, el texto original del artículo 1.683 establecía que la nulidad absoluta no se saneaba por el paso del tiempo. El Proyecto de 1842 establecía que "la nulidad absoluta (...) no puede sanearse por el lapso de tiempo ni por la ratificación de las partes"98. En los Proyectos de 1847 y 1853 se establecía que "no puede sanearse por la ratificación de las partes, ni por el lapso de tiempo" ${ }^{99}$. La redacción definitiva del artículo quedó recién en el Proyecto Inédito ${ }^{100}$.

v. La sanción que el Código Civil consagra para la contravención de leyes prohibitivas contemplada en el artículo 10 del Código Civil. Desde antiguo existe consciencia de que la infracción de leyes prohibitivas se sanciona con la total imposibilidad del acto para producir efectos, a menos que la ley establezca otra sanción ${ }^{101}$. En conformidad con ello, la redacción original de dicho artículo era "los actos que prohíbe la ley, son nulos y de ningún valor para producir efectos civiles, a menos que ella misma exprese lo contrario"102. Finalmente, el codificador se limitó a señalar que el acto es "nulo y de ningún valor" ${ }^{103}$, agregando luego que se trata de una "nulidad absoluta” (arts. 1.466 y 1.682 C.C.). El cambio en la redacción del artículo no cambió su sentido, pues continúa señalando que los actos prohibidos por las leyes son ineficaces civilmente, esto es, absolutamente nulos ${ }^{104}$.

96 Delvincourt (1834) p. 181.

97 Delvincourt (1834) p. 589.

98 Bello (1981a) p. 559.

99 Bello (1981a) p. 559.

100 Bello (1981a) p. 559.

$101 \mathrm{Al}$ respecto es clarificador lo indicado en el Título De Legibus del Código de Justiniano, que expresamente establece: “(...) si se hubiere hecho lo que por la ley se prohíbe hacer, no solo se tenga por inútil, sino también por no hecho, aun cuando el legislador solamente lo hubiere prohibido que se haga, y no se hubiere dicho especialmente, que deba ser inútil lo que se hizo. Pero también si se hubiere seguido alguna cosa de lo hecho con prohibición de la ley, o por causa de ello, mandamos que también esto sea inútil. // 1. Así, pues, conforme a la susodicha regla, por la que mandamos que en ninguna parte tenga valor lo hecho prohibiéndolo la ley, es cierto que ni tiene fuerza la estipulación de esta naturaleza, ni es de valor alguno el mandato, ni se admite el juramento". Cfr. C.1.14.5.

102 Entre las fuentes de este artículo A. Bello cita el título "De Legibus" del Código de Justiniano, si bien la referencia es a la Ley 3, la semejanza de redacción no deja lugar a dudas respecto de que la verdadera fuente es la ley 5 citada en la nota anterior. Así lo indica también el Código Civil argentino, el cual señala en las notas de su artículo 18, equivalente al artículo 10 del Código Civil chileno, que "es muy importante sobre este punto la L. Rom. 5, tít. 14, lib. 1 del Código. Cód. de Chile, art. 10, Cód. de Luisiana, art. 12”. Cfr. Nota de Vélez Sarsfield al artículo 18 del Código Civil argentino.

103 Nótese la semejanza con el Código Civil español cuyo artículo 6.3 señala: "Los actos contrarios a normas imperativas o prohibitivas son nulos de pleno derecho, salvo que en ellas se establezca un efecto distinto que el de nulidad para el caso de contravención". En la doctrina española relevante la nulidad de pleno derecho aquí sancionada corresponde a la inexistencia.

104 La equivalencia entre nulidad absoluta y falta de eficacia civil estaba clara en la doctrina nacional del s. XIX. En este sentido, en su comentario al artículo 10 del Código Civil, Robustiano Vera afirma "el Código francés 
vi. El artículo 1.447 tajantemente señala que los actos de los incapaces absolutos no producen "ni aun obligación natural", pero luego dispone que sus actos son absolutamente nulos (C.C. art. 1.682). Se ha justificado esta decisión señalando que esos actos tienen una apariencia de validez. Sin embargo, es dable concluir que A. BELLO señaló expresamente que la sanción era la nulidad absoluta para que nadie pensara que adolecen de nulidad relativa, pues se trata de un defecto "en la calidad o estado de las partes", que por regla general produce este tipo de ineficacia ${ }^{105}$.

En síntesis, múltiples antecedentes dan cuenta de que A. BELLo conocía la equivalencia conceptual entre nulidad absoluta e inexistencia, reconociendo su carácter insanable e ipso iure. No es posible afirmar que el codificador no pensó en la inexistencia como causal de ineficacia. Al contrario, todo indica que deliberadamente decidió que la nulidad absoluta fuera la ineficacia más grave que puede hacerse valer en contra de un acto, innovando en cuanto dispuso que esta podría sanearse por el paso del tiempo. Veremos luego el alcance de esta innovación.

\section{REFUTACIÓN DE ALGUNOS ARGUMENTOS A FAVOR DE LA INEXISTENCIA}

\section{A. Distinción ARTificial ENTRE REQUisitos DE EXISTENCIA Y VALIDEZ}

La discusión en torno al reconocimiento de la inexistencia como causal de ineficacia en el Código Civil tiene como punto de partida la distinción entre requisitos de existencia y validez del acto jurídico, que supuestamente recogería el Código Civil ${ }^{106}$. Así, RodríGUEZ GREZ afirma que una conclusión "muy obvia" es que "la ley contempla requisitos de existencia (esenciales o estructurales) y, solo en presencia de ellos, requisitos de validez (que acarrean la nulidad del acto o contrato). Si esto es así, la sanción no puede ser la misma, atendido el hecho de que ambos tipos de requisitos tienen entidad y naturaleza muy diversas" 107 . Sin embargo, la teoría del Derecho ha puesto en evidencia que las reglas en virtud de las cuales los particulares pueden celebrar actos jurídicos constituyen normas que confieren poderes normativos, también llamadas normas de competencia ${ }^{108}$; ellas establecen

guarda silencio a este respecto, tal vez porque siendo la lei regla de acción, todo acto ejecutado en su contra, es nulo y carece por consiguiente en absoluto de efectos civiles" (énfasis añadido). Cfr. VERA (1892) p. 9.

105 No puede perderse de vista que la principal división entre nulidad absoluta y relativa está referida a la naturaleza del defecto: (i) si se refiere al acto, la nulidad es absoluta; (ii) si se refiere a las partes, es relativa, vid art. 1.682 C.C.

106 En este sentido Julio Philippi argumentaba que "por algo se ha distinguido entre condiciones de existencia y de validez en los actos jurídicos, colocando entre las primeras la existencia de objeto y de causa, y entre las segundas, como requisito diferente, la licitud de dichos elementos”. Cfr. PhiLippi (2009) p. 357.

107 Cfr. Rodríguez Grez (1995) p. 45.

108 La identificación de este tipo de normas es atribuida a HART, quien la formuló en su obra The concept of law. "Hart caracterizó las normas que confieren poderes o normas de competencia como normas secundarias (distintas de las primarias, que son las que regulan conductas como obligatorias, prohibidas o permitidas) que atribuyen poderes tanto a autoridades públicas como a particulares para, siguiendo ciertos procedimientos y observando ciertos requisitos, realizar actos válidos en el sistema de referencia”. Cfr. Delgado Echeverría (2006a) $\$$ 1. Sin embargo, este mismo autor destaca que esta categoría de normas había sido ya identificada por 
los requisitos de producción de los actos jurídicos, de suerte que serán considerados tales aquellas manifestaciones de voluntad que respeten dichos requisitos, los demás simplemente carecen de reconocimiento jurídico ${ }^{109}$. En esta óptica la distinción conceptual entre requisitos de inexistencia y de validez carece de sentido ${ }^{110}$, toda vez que lo jurídicamente pertinente no es cuestionarse si un acto jurídico existe o no, sino preguntarse por los límites a partir de los cuales es posible afirmar que un acuerdo o declaración de voluntad produce efectos jurídicos ${ }^{111}$. Para determinar esos límites debe atenderse a lo que el acto precisa para ser eficaz conforme a derecho ${ }^{112}$.

El análisis de las disposiciones del Código Civil revela que esta concepción impera también en sus disposiciones y que, por el contrario, la distinción entre requisitos de existencia y validez es ajena a este cuerpo normativo. En efecto, el Código Civil solo se refiere a las condiciones necesarias para que los actos jurídicos sean eficaces, esto es, generen los derechos y obligaciones civiles queridos por las partes y correspondientes a su especie. En tal sentido puede verse:

i. El artículo 1.444 del Código indica que la falta de elementos esenciales de un acto jurídico implica que este "no produce efecto alguno o bien degenera en otro contrato diferente". Es decir, es ineficaz en cuanto no genera ningún derecho y obligación o bien produce derechos y obligaciones diferentes a las enunciadas por el tipo contractual que ha querido celebrarse.

ii. El artículo 1.445 enuncia los requisitos necesarios "para que una persona se obligue a otra por un acto declaración de voluntad”, es decir, para que el acto puesto en práctica por ella surta efectos civiles. En esta enumeración se encuentran todos los requisitos del acto jurídico: (i) voluntad exenta de vicio; (ii) objeto lícito; (iii) causa lícita; y (iv) capacidad. Nada en esa disposición indica una posible distinción entre requisitos de existencia y de validez, todos están en el mismo plano: son requisitos de eficacia del acto jurídico ${ }^{113}$.

Francisco de Suárez y, probablemente, es muy anterior a este mismo. Vid Delgado Echeverría (2006b) passim, especialmente p. 411.

109 Es interesante destacar que a partir de esta concepción los teóricos del Derecho han llegado a la conclusión de que la invalidez de un acto jurídico no pertenece a la categoría de las sanciones, pues la nulidad no es una consecuencia del incumplimiento de una norma de mandato, sino de la falta de presupuestos para que el acto emanado de la voluntad individual obtenga reconocimiento jurídico, esto es produzca efectos. Vid ATIENZA Rodríguez y Ruiz Manero (2003) pp. 719 ss.; Delgado Echeverría (2005) p. 9; Delgado Echeverría (2006a) y (2006b).

110 Así se explica que la en Francia la doctrina más autorizada describa esta distinción como los pilares de una doctrina clásica en desuso. GHESTIN (1988) p. 873.

111 Según la definición de Falzea, "effetto giuridico è ogni valore giuridico condizionato, ogni valore giuridico assunto dal diritto positivo sotto la condizione che sia prodotta una precedente situazione di fatto". Cfr. FALZEA (1962) p. 472.

112 En este sentido se ha señalado que "se califica de eficaz el negocio apto para producir los efectos que le correspondan según la regla negocial (la formada por la declaración de voluntad, la que se completa con las reglas jurídicas que a tal fin le sean aplicables); y correlativamente, se considera negocio ineficaz aquel al que cualquier obstáculo o defecto impide que despliegue sus naturales consecuencias”. Cfr. De Castro y Bravo (1985) p. 462.

113 La doctrina que postula la distinción entre requisitos de existencia y validez critica este artículo señalando que "el art. 1.445 confunde en realidad los requisitos de existencia y la validez de un acto jurídico". Cfr. CLARO Solar (1979) p. 10. En el mismo sentido los autores Ospina, quienes afirman que dicho artículo tiene un "de- 
En síntesis, la distinción entre requisitos de existencia y validez corresponde a una distinción doctrinaria desconocida para el Código Civil. Este solo se preocupa de la aptitud del para producir efectos jurídicos.

\section{B. La referencia al "VAlor" De Ciertos actos o Contratos no se opone a la “EXISTENCIA" DE LOS MISMOS ACTOS O CONTRATOS \\ El principal argumento en favor de la inexistencia como causal de ineficacia distinta} de la nulidad, es la literalidad de los artículos 1.444 y 1.681 del Código Civil. Según esta doctrina, tales artículos distinguen entre requisitos de existencia y validez, y el artículo 1.681 circunscribe la nulidad a la ausencia de un requisito de validez al indicar que "es nulo todo acto o contrato a que falta alguno de los requisitos que la ley prescribe para el valor del mismo acto o contrato, según su especie y la calidad o estado de las partes", "debiendo entenderse la expresión valor como sinónimo de validez"114.

Sin embargo, esta doctrina no explica por qué debe asignarse a la expresión "valor" del artículo 1.681 el significado validez, opuesto a existencia, en circunstancias que (i) como se vio, el Código Civil desconoce la distinción doctrinaria entre requisitos de existencia y validez; y (ii) en el Código Civil la expresión valor es empleada con diversos significados, refiriéndose más bien a la eficacia o bien ineficacia del acto en sentido amplio ${ }^{115}$. De esto último dan cuenta múltiples disposiciones que aluden al valor del acto en las diversas acepciones de eficacia ${ }^{116}$. En tal sentido puede verse:

fecto técnico (...) que consiste en la enumeración indiscriminada de los requisitos para la existencia de los actos jurídicos y de los requisitos para la validez de ellos". Cfr. Ospina y Ospina (1987) p. 85. Como se aprecia, la misma doctrina reconoce que la distinción no tiene cabida en el Código, pero insiste en forzar sus disposiciones para incorporarla.

114 Cfr. Vial del Río (2003) p. 240. En el mismo sentido señala Claro Solar: "con respecto a los contratos esta distinción aparece consagrada en los arts. 1.444 y 1.681. El primero expresa que son de la esencia de un contrato aquellas cosas sin las cuales o no produce efecto alguno, o degenera en otro contrato diferente, de modo que en todo contrato deben concurrir cosas, o sea requisitos, que son indispensables para la existencia del contrato, sin las cuales no produce efecto alguno, no existe. El segundo artículo expresa que es nulo todo acto o contrato, todo acto jurídico unilateral o bilateral, a que falte alguno de los requisitos que la ley prescribe para el valor del mismo acto o contrato según su especie y la calidad o estado de las partes; y agrega que la nulidad puede ser $a b$ soluta o relativa". Cfr. Claro Solar (1979) p. 11. Vid también Ospina y Ospina (1987) p. 444.

115 En este sentido "ineficacia es un concepto jurídico (...) que abarca diversas situaciones en las que los actos carecen de vigor, fuerza o eficiencia para lograr sus efectos. Dentro de esas situaciones queda incluida la nulidad o invalidez, de manera que la ineficacia tiene un alcance general que comprende también otros supuestos de ineficiencia, como los de caducidad, rescisión, resolución, revocación, cumplimiento de una condición suspensiva, etcétera”. Cfr. Cifuentes (1986) p. 570.

116 En un sentido semejante Lecaros Arthur advierte que "respecto de las palabras valor, validez, vale y otras expresiones semejantes, (...) creer que Bello utilizó en el mismo sentido estas expresiones, nos parece arbitrario y que envuelve una falta de observación de las disposiciones del Código, pues hay en este innumerables casos en que la palabra valor y sus derivados tienen un significado diverso que no se refiere a la presencia de vicios de nulidad". (Cfr. Lecaros (1997) p. 39) Sin embargo, la misma autora sostiene que en el artículo 1.681 la expresión "valor" tiene el significado de ausencia de un requisito de validez, sin dar ninguna explicación de sus dichos. 
i. El artículo 10, según el cual "Los actos que prohíbe la ley son nulos y de ningún valor". En esta disposición la ausencia de todo valor constituye un reforzamiento de la nulidad e indica la total falta de eficacia.

ii. El artículo 18, "en los casos en que las leyes chilenas exigieren instrumentos públicos para pruebas que han de rendirse y producir efecto en Chile, no valdrán las escrituras privadas, cualquiera que sea la fuerza de estas en el país en que hubieren sido otorgadas".

iii. El artículo 315, "el fallo judicial pronunciado en conformidad con lo dispuesto en el Título VIII que declara verdadera o falsa la paternidad o maternidad del hijo, no solo vale respecto de las personas que han intervenido en el juicio, sino respecto de todos, relativamente a los efectos que dicha paternidad o maternidad acarrea".

iv. El artículo 1.036, que señala "el testamento verbal no tendrá valor alguno si el testador falleciere después de los treinta días subsiguientes al otorgamiento (...)".

v. El artículo 1.226 que indica "se mirará como repudiación intempestiva, y no tendrá valor alguno, el permiso concedido por un legitimario al que le debe la legítima para que pueda testar sin consideración a ella”.

vi. Art. 1.702, "el instrumento privado, reconocido por la parte a quien se opone, o que se ha mandado tener por reconocido en los casos y con los requisitos prevenidos por ley, tiene el valor de escritura pública respecto de los que aparecen o se reputan haberlo subscrito, y de las personas a quienes se han transferido las obligaciones y derechos de estos".

vii. Artículo 1.716, "las capitulaciones matrimoniales se otorgarán por escritura pública, y solo valdrán entre las partes y respecto de terceros desde el día de la celebración del matrimonio, y siempre que se subinscriban al margen de la respectiva inscripción matrimonial (...). Sin este requisito no tendrán valor alguno”.

viii. Artículo 1.766 "el inventario y tasación, que se hubieren hecho sin solemnidad judicial, no tendrá valor en juicio (...)”.

ix. A esta larga lista de ejemplos se debe sumar todas aquellas disposiciones que se refieren a si el acto "vale" o no, las cuales también aluden a la eficacia del acto.

Ante esa amplia documentación, no existe razón alguna para interpretar la expresión valor del artículo 1.681 en el sentido de validez opuesto a existencia. En consecuencia, resulta una petición de principio sostener que necesariamente debe reconocerse la inexistencia como causal de ineficacia, porque el Código reservó la nulidad para la ausencia de requisitos de validez. De esta manera, corresponde apreciar la literalidad del artículo y aceptar que lo único que él señala es que falta de eficacia del acto toma el nombre de nulidad cuando se omite alguno de los requisitos relacionados de con (i) la especie del acto o (ii) la calidad o estado de las partes. El acento está puesto en las causales de ineficacia y no en el tipo ${ }^{117}$.

117 Código Civil, artículo 1.681: "Es nulo todo acto o contrato a que falta alguno de los requisitos que la ley prescribe para el valor del mismo acto o contrato, según su especie y la calidad o estado de las partes. // La nulidad puede ser absoluta o relativa”. 


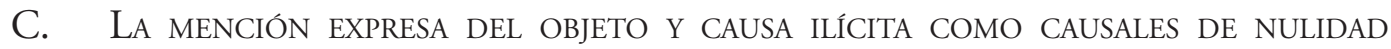 ABSOLUTA TIENE EXPLICACIÓN HISTÓRICA}

Otro argumento en favor de la distinción entre inexistencia y nulidad absoluta está dado por el tenor literal del artículo 1.682 que expresamente sanciona con nulidad absoluta al acto que tiene objeto o causa ilícitos, pero no menciona la falta de causa o bien la falta de objeto. Sin embargo, la comparación de algunas de las fuentes empleadas por A. BELLO en la redacción del Código Civil revela una discordancia en cuanto a la sanción aplicable al caso de causa u objeto ilícito, por tanto, al mencionarlos expresamente, el redactor adopta una posición en esta discusión.

En efecto, Delvincourt, enumera las causales de nulidad (sin distinguir entre absoluta y relativa) incluyendo expresamente la falta de objeto, la falta de causa, y la causa falsa o ilícita ${ }^{118}$. Luego, en sus explicaciones, DeLvincourt aclara que la nulidad producida por causa ilícita es nulidad relativa, pues se trata de un defecto que empece a las partes (ex unâ tantùm parte $)^{119}$.

Por el contrario, PothieR, al tratar los elementos constitutivos del contrato sostiene que la causa ilícita es causal de nulidad y no rescisión. En la terminología adoptada por BELLO: causales de nulidad absoluta y no relativa. En efecto, conforme se vio antes, POTHIER afirma que el acto es nulo cuando carece de uno de sus elementos esenciales, entre los cuales se incluye la causa ${ }^{120}$. Sin embargo, según este autor el acto es también nulo "cuando la causa por la cual el compromiso ha sido contratado es una causa que hiere la justicia, la buena fe, o las buenas costumbres" ${ }^{121}$.

En suma, en cuanto a la causa y objeto ilícitos A. Bello se apartó de la doctrina de Delvincourt y adoptó la posición contraria, esto es, que la causa y objeto ilícitos dan lugar a nulidad absoluta del acto y no a una simple rescisión. Con estas consideraciones se explica que los haya mencionado expresamente en el artículo 1.682 y no haya dicho nada respecto de la falta de objeto o de causa. En estos casos no había discusión que zanjar.

\section{LA FALTA SOLEMNIDADES NO COMPORTA EL TOTAL DESCONOCIMIENTO JURÍDICO DEL ACTO}

Desde antiguo se reconoce que existen tres formas de perfeccionamiento de los actos jurídicos: (i) la entrega de la cosa, que da lugar a los contratos reales; (ii) el mero consentimiento, que da lugar a los contratos consensuales; y (iii) el cumplimiento de una solemnidad, que da lugar actos solemnes.

La exigencia de una solemnidad para el perfeccionamiento de un acto jurídico obedece a que a la sociedad le interesa que haya certeza y publicidad sobre la celebración de ciertos actos que considera especialmente relevantes, ya sea por la importancia económica del bien sobre el cual recaen (compraventa de bienes raíces) o bien por la relevancia social

\footnotetext{
118 Las otras causales son error, fuerza, dolo, lesión, falta de autorización del marido, menor edad, interdicción y falta de las formalidades requeridas para la validez del acto. Delvincourt (1834) p. 182.

119 Delvincourt (1834) p. 589.

120 Pothier (2007) p. 42.

121 Pothier (2007) p. 43.
} 
que revisten (matrimonio). Así, que el acto sea solemne significa que el solo consentimiento es insuficiente para que el acto produzca los efectos civiles deseados por las partes, pues se requiere el cumplimiento de una determinada ritualidad ${ }^{122}$.

Sin embargo, lo anterior no significa que el ordenamiento jurídico desconozca del todo los efectos que el acto de hecho pueda haber generado, mirándolo como inexistente, semejante interpretación confunde eficacia con relevancia jurídica ${ }^{123}$, es esta última la que permite atribuir ciertas consecuencias jurídicas a los actos imperfectos por falta de solemnidad $^{124}$ : (i) generan obligaciones naturales ${ }^{125}$; y (ii) hay lugar a la responsabilidad precontractual cuando, una vez formado el consentimiento, una de las partes se niega injustificadamente a cumplir con la solemnidad ${ }^{126}$.

Se ha intentado explicar tales efectos señalando que ellos no implican un reconocimiento jurídico del acto, pues "los efectos laterales u ocasionales derivados de la voluntad o de la apariencia, los asigna la ley y no nacen del negocio inexistente" ${ }^{127}$. Sin embargo, ello no impide que el acto tenga consecuencias jurídicas, cuestión que la nada no podría generar. Por lo demás, la doctrina moderna reconoce que todos los efectos emanados de los actos jurídicos son tales precisamente porque el ordenamiento jurídico así lo determina: una manifestación de voluntad no produce más efectos que aquellos que el ordenamiento jurídico le reconoce o asigna ${ }^{128}$. En suma, si la ley asigna alguna consecuencia a un acto, es precisamente porque asume su relevancia, aunque no su eficacia.

122 Así se explica que alguna doctrina haya llegado a afirmar que el cumplimiento de la solemnidad constituye la manifestación de voluntad; sin embargo voluntad y solemnidad son requisitos independientes: puede perfectamente haberse expresado la voluntad e incluso haberse formado el consentimiento, pero mientras no se cumpla la solemnidad el acto no se perfecciona, es decir, no genera sus efectos jurídicos típicos.

${ }^{123}$ Para la contraposición entre eficacia y relevancia jurídica, vid Falzea (1962) pp. 462 ss.; Tommasini (1972) pp. 580 ss.

124 En este sentido es destacable el artículo 6A de la Ley 18.046 que señala que la falta de escritura pública produce la nulidad de pleno derecho e insanable de la sociedad anónima y, sin embargo, agrega que "si existiere de hecho dará lugar a una comunidad entre sus miembros. Las ganancias y pérdidas se repartirán y soportarán y la restitución de los aportes se efectuará entre ellos con arreglo a lo pactado y, en subsidio, de conformidad a lo establecido para las sociedades anónimas" (énfasis añadido). El primitivo artículo $6^{\circ}$ de esta ley era un argumento de la doctrina para afirmar que el ordenamiento jurídico reconocía la inexistencia, sin embargo, fue modificado para reemplazar la referencia a la inexistencia por nulidad, en los términos antes expresados, adecuando así la terminología a los verdaderos efectos que la situación genera. Véase Puga VIaL (2011) pp. 111 ss.

125 Según el artículo 1.470 № $3^{\circ}$, son obligaciones naturales "las que proceden de actos a que faltan las solemnidades que la ley exige para que produzcan efectos civiles". La doctrina nacional ha discutido el alcance de esa disposición, en el sentido si ella se refiere a todo tipo de actos jurídicos -incluidos los contratos- o bien solo a los actos jurídicos unilaterales. En esta discusión resulta interesante destacar que Claro SOLAR, propulsor de la teoría de la inexistencia en Chile, afirma el alcance general de la disposición. En su concepto, incluso los contratos solemnes imperfectos por falta de solemnidad generan obligaciones naturales. Los detalles de esta discusión pueden revisarse en CONCHA MACHUCA (2014).

126 Véase Corte Suprema, Rol No 1872-2010, con comentario en San Martín Neira (2013) p. 315-322.

127 Rodríguez Grez (1995) p. 33.

128 En este sentido enseña Flume que "los efectos jurídicos producidos en virtud de la autonomía privada son siempre, ciertamente, efectos jurídicos legales, en la medida en que el acto de autonomía privada solo tiene eficacia jurídica en virtud del Ordenamiento jurídico. El Ordenamiento jurídico se limita, sin embargo, a atribuir eficacia jurídica a la configuración autónomo-privada en la medida en que la reconoce". Cfr. Flume (1998) p. 25. En un sentido similar afirma Betti que "fatti giuridici sono pertanto i fatti ai quali il diritto attribuisce rile- 
Por su parte, el artículo 1.682 del Código Civil señala que la "nulidad producida por la omisión de algún requisito o formalidad que las leyes prescriben para el valor de ciertos actos o contratos en consideración a la naturaleza de ellos (...) son nulidades absolutas”. En consecuencia, para la ausencia de solemnidades está expresamente prevista la nulidad absoluta del acto y no puede hablarse de inexistencia ${ }^{129}$.

En síntesis, el tenor del artículo 1.682 y el hecho de que la falta de solemnidades no prive al acto de relevancia jurídica, lleva a concluir que, incluso aceptando la procedencia de la inexistencia como causal de ineficacia distinta de la nulidad, la ausencia de solemnidades conlleva exclusivamente la nulidad absoluta del acto ${ }^{130}$.

\section{NECESIDAD DE SENTENCIA JUDICIAL COMO CARACTERÍSTICA COMÚN A LA INEXISTENCIA Y A LA NULIDAD ABSOLUTA}

Según se dijo antes, para ZaCHARIAE la consecuencia práctica de la distinción entre inexistencia y nulidad estaba dada por el hecho de que la inexistencia opera ipso iure, es decir, no requería de una sentencia judicial que la declarara, mientras que la nulidad (en cualquiera de sus formas) sí la requería. En Chile, sus partidarios, han mantenido la operatividad ipso iure como una característica de la inexistencia. En este sentido se dice que el acto inexistente no produce efecto jurídico alguno, en cambio el nulo produce sus efectos mientras el juez no declare la nulidad ${ }^{131}$. La consecuencia práctica de este razonamiento sería, por ejemplo, la siguiente: si se celebra una compraventa de bien raíz por escritura privada y se efectúa el pago del precio, puede demandarse derechamente la restitución de lo pagado, sin necesidad de solicitar un pronunciamiento judicial sobre la ineficacia del acto. Sin embargo, es necesario observar que el fundamento de dicha repetición será la inexistencia del acto y, por tanto, para acceder a lo pedido el juez deberá previamente pronunciarse sobre la (in)eficacia del acto celebrado. Lo mismo ocurriría si se demandara la entrega del

vanza giuridica nel senso di mutare le situazioni ad essi preesistenti e di configurare situazioni nuove, cui corrispondono nuove qualificazioni giuridiche". Cfr. Betti (2002) p. 9. Vid también Tommasini (1972) p. 579; Delgado ECHEVERría (2006) p. 21.

129 Cierta parte de la doctrina ha intentado sostener que la falta de una solemnidad genera inexistencia, pues "la nulidad absoluta se produce cuando la formalidad está establecida para el pleno valor del acto y no para su existencia”, según la literalidad del artículo 1.681. (Lecaros (1997) p. 18). Sin embargo, como se vio anteriormente, no hay razones suficientes para sostener que este artículo emplea la expresión valor en el sentido de validez, opuesto a existencia.

130 En este mismo sentido, no obstante ser partidario de la inexistencia, Julio Philippi señala: "la expresión empleada por el Código al hablar de "requisito o formalidad" es sumamente amplia, y comprende, en todo caso, las formalidades o solemnidades esenciales, de manera que, a pesar de los términos empleados por el ya citado artículo 1.701, la omisión de dichas solemnidades parece estar penada expresamente con la nulidad. // Por lo demás, diversas otras disposiciones del Código Civil, corroborarían esta conclusión, como por ejemplo los artículos 1.443 y 1.470 No 3, que hablan de las formalidades a que están sujetos determinados actos o contrato, sin cuyo cumplimiento no producen efectos civiles. Si dichos actos o contratos, a pesar de la omisión de las formalidades, son capaces de engendrar obligaciones naturales, parece evidente que no podrán considerarse inexistentes”. Cfr. PHiLippi (2009) pp. 354-355.

131 Esta idea está claramente imbuida por la concepción procesal de la nulidad imperante en la doctrina francesa a partir de la obra de Japiot. Vid supra, apartado II D. 
bien y, como excepción, el demando opusiera la inexistencia del acto por falta solemnidad. Como se aprecia, será igualmente necesario un pronunciamiento judicial en torno a la ineficacia del acto $^{132}$. En consecuencia, el problema de la teoría de la inexistencia se reduce a determinar si en el ordenamiento jurídico chileno puede alegarse la inexistencia de un acto como fundamento de una acción que pretenda alterar el statu quo de una relación jurídica, más allá del plazo de prescripción de la acción de nulidad absoluta.

En efecto, incluso aquellos ordenamientos en que se reconoce la eficacia ipso iure de la nulidad se han preocupado de regular la acción de nulidad y adscriben consecuencias prácticas bien precisas a dicha modalidad de ineficacia: (i) es posible que el juez la declare de oficio ${ }^{133}$ y (ii) la acción de nulidad es imprescriptible ${ }^{134}$.

En Chile, la primera de dichas consecuencias ha sido expresamente asignada a la nulidad absoluta, "cuando aparece de manifiesto en el acto o contrato", es decir, cuando el acto no reviste ni aun apariencia de legitimidad. Es más, podría decirse que en Chile la nulidad absoluta opera de pleno derecho ${ }^{135}$, pero ello no significaría que puedan desde luego desconocerse las consecuencias fácticas del acto absolutamente nulo.

En efecto, el Mensaje del Código Civil y otros antecedentes dan cuenta de que para A. BELlo una diferencia entre nulidad relativa y absoluta era la que solo la primera daba lugar a la rescisión del acto, es decir, a su privación de efectos, mientras que la segunda no y, por tanto, operaba de pleno derecho. Así, el Mensaje indica que se ha seguido a los Códigos francés, de las Dos Sicilias y al sardo en cuanto a que a en ellos "el contrato celebrado por un menor sin el consentimiento del guardador no es nulo ipso iure, aunque puede rescindirse" ${ }^{136}$. Por su parte, el artículo 1.682 inciso final, al establecer la nulidad relativa

132 Los partidarios de la inexistencia reconocen que la eficacia de pleno derecho no significa que la inexistencia constituya "un caso de autotutela jurídica. Quien asigna efectos a un acto tentado deberá ocurrir al tribunal competente, lo propio deberá hacer quien pretende retrotraer una situación de hecho cuando su alteración se funda en un acto inexistente”. Cfr. Rodríguez Grez (1995) p. 59. Este autor intenta salvar la situación sosteniendo que es muy diferente que el juicio se funde un acto nulo, que genera efectos provisionales, a que se funde en un acto inexistente, en cuyo evento el acto no genera efecto provisional alguno (ibidem), pero el autor no explica qué consecuencia práctica derivaría de esa diferencia.

133 En este sentido señala De Castro y Bravo, "esta eficacia inmediata de la nulidad, se manifiesta del modo más llamativo, en el hecho de que los Tribunales de Justicia pueden apreciar "de oficio" la existencia de la nulidad; es decir, aunque la declaración de nulidad no haya sido pedida por ninguna de las partes contendientes". Cfr. DE Castro y Bravo (1985) p. 476.

134 El mismo autor recién citado afirma que el carácter definitivo de la nulidad (absoluta) "se manifiesta también en que puede subsistir ilimitadamente la posibilidad de que se le tenga en cuenta. El tiempo no convalida los negocios nulos, no hace válido retroactivamente el negocio simulado ni el negocio prohibido. En correspondencia con ello, la llamada acción de nulidad, conforme a su peculiar naturaleza, no se extingue por caducidad (la del art. 1.301) ni por prescripción (la del art. 1.964)”. Cfr. De Castro y Bravo (1985) p. 480.

135 En el pasado, esta posición ha sido defendida por don José Clemente Fabres quien funda su razonamiento en la circunstancia de que la nulidad absoluta sería equivalente a la inexistencia jurídica del acto. Véase FABRES (1908) pp. 139 ss. En la doctrina reciente esta idea ha sido defendida por Baraona en múltiples ocasiones (vid Baraona, 2005a, 2005b, 2007 y 2012) y de último por Alcalde. Con todo, este autor se preocupa de aclarar que esta idea no se opone a la necesidad de declaración judicial de la nulidad, la cual "es exigida por la ley como requisito de certeza que indica desde cuándo existen las obligaciones restitutorias entre las partes (artículo 1.687), que son incompatibles, por su propia naturaleza, con la subsistencia de las obligaciones aparentes nacidas del acto o contrato absolutamente nulo". Cfr. AlCalde (2010) p. 69.

136 En este mismo sentido, BARAONA (2007) p. 540. 
como la regla residual de nulidad, señala que "cualquiera otra especie de vicio produce nulidad relativa, y da derecho a la rescisión del acto o contrato". Con esta expresión, A. BELLO estaría indicando que la nulidad relativa tiene la virtud de privar de efectos al acto (rescindir), mientras que la nulidad absoluta no tiene esa virtud, porque opera ipso iure $e^{137}$. Sin embargo, ya en la primera versión del actual artículo 1.681, contenida en el Proyecto de 1842, A. Bello señalaba que la "nulidad [absoluta o relativa] debe ser judicialmente declarada”, frase que desapareció en la versión de 1853. En suma, el carácter pragmático de A. BeLlo lo llevó a regular las consecuencias de la nulidad judicialmente pronunciada (art. $1.687^{138}$ ), sin distinguir entre absoluta y relativa, lo que evidencia que en fin de cuentas lo relevante para la acción de nulidad son las consecuencias que en la práctica se hayan generado $^{139}$. En este punto es conveniente recordar las lúcidas palabras de DOMAT cuando señalaba que, a pesar de su carácter originario, en los casos en que el acto haya dado lugar a consecuencias, es necesaria la sentencia judicial que declare la nulidad, a fin que operen las restituciones a que haya lugar según las circunstancias ${ }^{140}$.

En la doctrina contemporánea esta situación es advertida por De CASTRO y Bravo quien, a propósito del carácter ipso iure de nulidad en España, afirma que en todo caso la intervención judicial "será inevitable en algunos casos; así, cuando se requiera para vencer la resistencia de quienes sostengan la validez y, en especial, cuando sea necesaria para borrar la apariencia de validez de que goce el negocio; por ejemplo, si está autorizado en documento fehaciente o inscrito en algún Registro público. Más aún, en estos casos no se

137 Cabe destacar que para A. Bello la rescisión consistía precisamente en la privación de efectos del acto, de las cuales la nulidad relativa era una de sus causales, no un sinónimo, como generalmente se enseña. De esta circunstancia da cuenta el artículo 1.865 del Proyecto de 1.853, finalmente no incluido en el Código, que señalaba: "Los contratos que, válidos en principio, pueden rescindirse por alguna causa que han previsto las leyes, están sujetos a las mismas reglas que los contratos que adolecen de nulidad relativa; salvo en cuanto se hayan dictado reglas especiales para ciertos contratos o para ciertas causas de rescisión". Si bien no lo dice expresamente, es dable suponer que esta forma de ver la nulidad y la rescisión fue tomada del Proyecto de Código Civil español comentado por García GoYena, que distinguía entre nulidad y rescisión en cuanto a sus causas, pero no en cuanto a sus efectos. De hecho, en sus comentarios al artículo 1.190 del Proyecto español, este autor afirma "que los resultados de la rescisión y nulidad vienen á ser casi iguales: así es que en este artículo se dispone para la segunda lo mismo que en el artículo 1.172 para la primera: el contrato declarado nulo no ha existido civilmente, y lo nulo no puede, en tesis general, producir efecto alguno". Cfr. GarCía (1852) p. 198. En este mismo sentido, calificando la enseñanza tradicional de "mito jurídico", AlCAlde (2010) pp. 47 ss.; también BaraOna (2007) p. 540.

138 Nótese que la versión original de este artículo, contenida en el tit. XIX, art. 10 del Proyecto de 1842, utilizaba la expresión "declarada", en lugar de "pronunciada". Al igual que los artículos 1.683 y 1.684, que hablan de "declarada", el primero en el sentido que el juez sí puede "declarar" la nulidad de oficio y en el segundo en el sentido que no puede hacerlo. Ciñéndose a un análisis exegético, podría decirse que A. BELlo advierte que la nulidad absoluta es declarada por el juez, precisamente porque opera de oficio, a diferencia de la nulidad relativa. El cambio de redacción en el artículo 1.687 tendría, entonces, por objetivo ampliar la disposición a los casos en que la sentencia del juez no es meramente declarativa, sino también constitutiva, pero la base es demasiado débil para sustentar una afirmación en este sentido.

139 El artículo 1.687 guarda perfecta armonía (casi literal) con los dichos de Delvincourt, a propósito de la del efecto de la sentencia que admite la demanda de nulidad (DeLvincourt (1834) p. 185), pero este autor también reconoce la imprescriptibilidad de la excepción de nulidad (DelvincourT (1834) p. 597). En suma, la necesidad de sentencia judicial se advierte exclusivamente cuando en la práctica se han producido efectos jurídicos que revertir.

140 Vid supra, nota 30. 
solicita del Juez que cambie, anule o resuelva la situación existente, sino que se le pide una declaración sobre la realidad jurídica existente. Sentencia declarativa que bastará y servirá para remover los obstáculos que la apariencia de validez o la resistencia de la otra parte puedan oponer" 141 .

\section{EL "SANEAMIENTO DE LA NULIDAD ABSOLUTA" EXTINGUE LA ACCIÓN DE NULIDAD PERO NO COMPORTA LA DESAPARICIÓN DEL VICIO}

La principal razón de la discusión en torno a la inexistencia en Chile ha sido el artículo 1.683 C.C., que en su actual redacción señala que la nulidad absoluta "no se sanea por lapso de tiempo que no pase de diez años". Los partidarios de la inexistencia afirman que este plazo no puede referirse a un acto jurídicamente inexistente, pues la nada no puede transformarse por el solo paso del tiempo ${ }^{142}$. De esta forma, la inexistencia sería útil para "negar los efectos propios del transcurso del tiempo como modo de saneamiento"143.

Aunque no se pone de relieve, esa forma de interpretar el artículo 1.683 supone aceptar que el plazo allí contemplado tiene la virtud de hacer desaparecer el vicio y, por tanto, el acto mismo se tornaría jurídicamente válido. Sin embargo, esa no es la única interpretación posible. En efecto, también puede afirmarse que se trata de un plazo de extinción (prescripción extintiva o caducidad, según se determine ${ }^{144}$ ) de la acción de nulidad, pero que ello no comporta la desaparición del vicio, sino solo que no puede ejercerse la acción de nulidad más allá de los 10 años. Como veremos, esta resulta ser la interpretación más razonable.

Por otro lado, se ha señalado que la inexistencia puede ser útil "para impedir que encuentre asilo en contrato de tal modo irregular una cierta prescripción adquisitiva" ${ }^{145}$. Este razonamiento evidencia que el propósito práctico de la teoría de la inexistencia es revertir los efectos a que de hecho haya dado lugar el acto inexistente en cualquier tiempo, para ello se fundan en la imprescriptibilidad de la acción de inexistencia ${ }^{146}$. Sin embargo, no

141 De Castro y Bravo (1985) p. 475.

142 En este sentido Rodríguez Grez afirma: "si se concluye que la "inexistencia”, por carecer de un estatuto jurídico orgánico en nuestra legislación, debe ser asimilada a la nulidad absoluta, se llega a la conclusión de que quien niega la titularidad de un derecho fundado en un acto jurídico tentado, solo podría reclamar la falta de efectos durante el lapso de tiempo instituido en la ley al regular la nulidad. // Esta conclusión nos parece disparatada (...)”. Cfr. Rodríguez Grez (1995) pp. 48-49.

143 Domínguez (2012) p. 179.

144 En la doctrina nacional no hay total consenso sobre las razones que justifican la distinción entre prescripción extintiva y caducidad, como tampoco sobre las consecuencias prácticas de la distinción. (Por todos, véase BARCiA (2012) pp. 115-163). Atendido que la naturaleza jurídica del plazo contemplado en el artículo 1.683 (caducidad o prescripción) no altera las conclusiones de este artículo, pero sí podría tener consecuencias prácticas importantes, nos referiremos genéricamente a la extinción de la acción de nulidad.

145 Domínguez (2012) p. 179.

146 En este sentido se dice que "el acto "inexistente" que carece de apariencia (...) no confiere posesión de los objetos sobre los que recae y, por lo mismo, el plazo de diez años de que trata el artículo 1.683 no puede dotarlo de existencia y poder vinculante (validez) o atribuirle otras consecuencias”. Cfr. Rodríguez GrEz (1995) p. 52. Sin embargo, cabe destacar que este mismo autor reconoce que el sujeto que haya adquirido la tenencia material de una cosa en virtud de un acto inexistente podrá acreditar su posesión mediante actos materiales de 
puede perderse de vista que una acción semejante tendría un carácter meramente declarativo y, por tanto, los efectos patrimoniales del acto quedarían sujetos a las reglas generales de prescripción adquisitiva y extintiva. Según veremos, este era precisamente el objetivo perseguido por A. BELLo la contemplar el saneamiento de la nulidad absoluta.

\section{A. El saneamiento de la nulidad absoluta en el Código de Bello: INTERPRETACIONES POSIBLES \\ Conforme se dijo anteriormente, en los Proyectos de Código Civil se consagraba el} carácter insanable de la nulidad absoluta, tanto por voluntad de las partes como por el paso del tiempo. Sin embargo, A. Bello se había preocupado de señalar que ese carácter insanable no empecía la prescripción adquisitiva extraordinaria de los bienes recibidos en virtud del acto nulo. Así, en los Proyectos de 1847 y de 1853 el artículo correspondiente al actual 1.683 establecía que la nulidad absoluta "no puede sanearse (...) por el lapso de tiempo. No podrá, sin embargo, alegarse contra una posesión pacífica que haya durado treinta años" ${ }^{147}$. En el Proyecto Definitivo ${ }^{148}$, A. BELLo cambió la redacción del artículo señalando derechamente el saneamiento de la nulidad por el paso del tiempo. Corresponde entonces preguntarse cuál es el alcance de este cambio en la redacción de la norma: ¿̇significa que se desaparece el vicio o que se extingue la acción de nulidad?

La doctrina ha sido más bien contradictoria al respecto. BARros ERRÁzUrIz enseñaba que "la prescripción de treinta años que establece nuestro Código para la nulidad absoluta no tiende a dar existencia legal a un acto prohibido por la ley, sino a destruir el efecto de las acciones que pasados treinta quisieran intentar contra el que tiene en su favor una situación de hecho prolongada durante tanto tiempo"149. En los años recientes esta tesis ha sido retomada por BARAONA, quien afirma que el saneamiento de la nulidad absoluta significa que pasados diez años se extingue la acción de nulidad, sin que se pueda demandar que se declare la nulidad de un acto, pero ello no significa la convalidación del acto, ni la desaparición del vicio ${ }^{150}$. En síntesis, según esta doctrina, una vez transcurridos los diez años a que se refiere el artículo 1.683, la situación hasta entonces existentes se consolida, sin que nadie pueda ejercer acción alguna destinada a transformar el statu quo.

Sin embargo, para algunos autores el saneamiento de la nulidad supone la desaparición del vicio, e incluso algunos se contradicen al interior de una misma obra. Así, AlesSANDRI BESA afirma que el saneamiento de la nulidad absoluta "se trata de una prescripción extintiva de la acción de nulidad" con un plazo especial más extenso y coincidente con la

\footnotetext{
aquellos a que da lugar el dominio, "puesto que del acto jurídico inexistente no se derivaría antecedente jurídico suficiente para establecer el animus en la posesión ni su adquisición”. Ídem, p. 65. Ante este último razonamiento, el hecho de que el acto inexistente no confiera posesión tendría consecuencia práctica solo en los casos en que el detentador de la cosa no pueda demostrar que ha actuado como dueño.

147 Vid Bello (1981a) p. 559.

148 Se conoce como "Proyecto Definitivo" aquel que A. Bello entregó al Presidente de la República y que fue sometido a la aprobación del Congreso Nacional el 22 de noviembre de 1855. Alessandri Rodríguez et al. (2011), t. I, p. 89.

149 Cfr. Barros Errázuriz (1932) p. 288.

150 BaraOna (2012) pp. 57 ss.
} 
prescripción adquisitiva extraordinaria ${ }^{151}$. Sin embargo, luego señala que "el citado artículo [1.683] dispone que es la nulidad misma la que se sanea por el lapso de tiempo de quince años, o sea, se refiere al saneamiento de la nulidad y no de la prescripción de las acciones de nulidad que corresponden a los interesados en pedirla"152.

Esta última interpretación encuentra un fuerte sustento en el hecho de que A. BELLO cambió la redacción original del artículo para referirse al saneamiento de la nulidad y no a la extinción de la acción. Sin embargo, estimamos que la primera interpretación tiene asidero en el efecto práctico perseguido con la inclusión de la norma (consolidación de las situaciones jurídicas) y en el hecho de que el sistema concebido por A. BELlo es sustancialmente coincidente con el tratamiento que ordenamientos jurídicos de la misma tradición hacen del argumento, específicamente el italiano y español.

\section{B. El SANEAMIENTO DE LA NULIDAD SIGNIFICA SOLAMENTE EXTINCIÓN DE LA ACCIÓN}

El ordenamiento jurídico exige una serie de requisitos para que la potestad de los particulares produzca el cambio normativo deseado, esto es para que el acto obtenga reconocimiento jurídico y genere derechos y obligaciones queridos por sus autores (C.C. arts. 1.444 y 1.445). Si alguno de esos requisitos falta, el acto carece de aptitud para producir efectos o bien produce efectos diferentes a los que su regulación típica contempla. En este último caso se dice que el acto "degenera en un contrato diferente"153.

Sin embargo, incluso un acto abiertamente defectuoso (como una compraventa sin cosa) puede dar lugar ciertos intercambios patrimoniales o "efectos materiales". Así, si las partes de una compraventa de bienes raíces, celebrada por escritura privada, realizan el intercambio de la cosa y del precio, jurídicamente no han cumplido sus obligaciones de vendedor y comprador, pues la compra no ha llegado a perfeccionarse (jurídicamente nullum est - no existe). En este sentido, lleva razón Rodríguez Grez cuando sostiene que "si, en razón del falso concepto sobre la existencia y obligatoriedad del acto tentado, se procede al desplazamiento material de las cosas que son objeto del acto inexistente, es claro que este hecho material no corresponde al cumplimiento de una obligación ni al ejercicio de un derecho. Por lo tanto, todo queda en el ámbito meramente fáctico y no jurídico"154. El punto entonces no es saber si esas consecuencias son jurídicas o fácticas, sino si puede el ordenamiento jurídico desconocerlas ad eternum o en algún momento debe producirse la consolidación. La respuesta pareciera estar más bien en la segunda alternativa ${ }^{155}$.

\footnotetext{
151 Alessandri Besa (1949) p. 508.

152 Cfr. Alessandri Besa (1949) p. 535.

153 La eficacia del acto jurídico está dada por los efectos jurídicos proyectados por el acto conforme a la regulación dada por las partes, pero la aptitud del acto para producir tales efectos está determinada por el ordenamiento jurídico, no depende de la voluntad de las partes, sino del cumplimiento de ciertos requisitos. En estos términos debe ser entendido el artículo 1.445 del Código Civil y a ello se refiere el artículo 1.681 al sancionar con nulidad la ausencia de uno de esos requisitos. Sobre la noción de eficacia en los términos aquí expresados, véase Flume (1998) p. 25 ss.; Díez-Picazo (2007) p. 517 ss.

154 Rodríguez Grez (1995) p. 64.

155 Estamos conscientes de que en este caso el problema se agudiza por la imposibilidad de inscribir el título en el Registro del Conservador de Bienes Raíces y la discusión en torno a si es posible poseer bienes raíces (y por tanto adquirir por prescripción) sin la competente inscripción. Sin embargo, esta discusión es ajena a la
} 
En principio, la consolidación de la situación se logra estableciendo que la nulidad no puede invocarse en contra de la prescripción adquisitiva extraordinaria de los bienes recibidos en virtud del acto anómalo, sin embargo ello no es suficiente, pues, al establecerlo de esa manera, podría entenderse que quedan a salvo las acciones personales tendientes a repetir las sumas de dinero $\mathrm{u}$ otras cosas no susceptibles de adquirirse por prescripción ${ }^{156}$. Siendo así, A. Bello habría buscado una fórmula que abarcara la consolidación de todos los efectos derivados del acto, empleando para ello la expresión saneamiento, pero esta circunstancia no autoriza para concluir que la intención del legislador era hacer desaparecer el vicio y permitir que un acto jurídicamente imperfecto comenzara desde entonces a producir efectos. En este sentido pueden utilizarse las palabras PASQUAU LIAŃO cuando, a propósito de su defensa de la prescripción de la acción de nulidad en el Derecho español, señala: "lo que prescribe (...) es la acción de nulidad y no la nulidad misma. La prescripción opera en el plano de la pretensión de un pronunciamiento judicial sobre la nulidad del contrato, y no en el de la existencia de la causa de nulidad. Decir que prescribe la acción de nulidad es afirmar que pasado cierto tiempo y dadas ciertas condiciones, ya no podrá discutirse si el contrato es válido o es nulo, y por tanto sus efectos serán indestructibles, por más que ontológicamente el contrato adoleciera de un vicio de nulidad. Dicho de otro modo, por más que se declare extinguida por prescripción una acción de nulidad, el contrato no habría quedado "purificado" de sus vicios" 157.

En Chile, esta interpretación del artículo 1.683 C.C. encuentra apoyo en las fuentes utilizadas en su redacción, específicamente en la doctrina de DelvincourT, quien, a pesar del carácter insanable de la nulidad absoluta, se pregunta por la duración de la acción para solicitarla y concluye que ella prescribe en el plazo de 10 años establecido en el artículo 1.304 del Código Civil francés, plazo que aplicaría tanto para nulidad relativa como absoluta. En cambio, agrega, la excepción de nulidad sería imprescriptible ${ }^{158}$, precisamente por-

nulidad o inexistencia de la compraventa o incluso de la tradición y constituye más bien una decisión política respecto a quién se le dará protección jurídica: al que detenta materialmente la tierra o al que tiene un título inscrito. De hecho, para los casos en que este problema se presenta con mayor frecuencia, las compraventas de pequeña propiedad raíz, el legislador ha dictado normas especiales que reconocen un valor jurídico propio a dichas compraventas y permiten el ingreso de estas propiedades al Registro del Conservador. Esta es precisamente la función que cumple el DL 2.695 de 1979.

156 Un problema análogo puede observarse en el Derecho español, en que la acción restitutoria personal prescribe en 15 años, mientras que la prescripción adquisitiva se produce a los 30 años. Dado que, salvo raras excepciones, existe consenso en que la acción de nulidad es imprescriptible, en un contrato de compraventa radicalmente nulo, el comprador tiene 15 años para deshacer las consecuencias patrimoniales del acto, mientras que el vendedor 30. Vid Pasquau Liaño (2006) \$ 10. a).

157 Cfr. Pasquau Liaño (2006) $\$$ 5. Cabe señalar que para este autor la acción de nulidad es en todo prescriptible y, en su concepto, "lo que se denomina acción "meramente declarativa de nulidad", como pretensión que se agota en la constatación judicial de la existencia del vicio de nulidad, es una entelequia”. Cfr. PASQUAU LIAÑO (2006) \$ 7.b).

158 Efectivamente, conciliando la prescripción de la acción de nulidad con la imprescriptibilidad de la excepción, este autor afirma: "Appliquons ces príncipes á une espèce. Un interdit a vendu une maison, et l’a livrée. (...). E bien alors, il a dix ans, á compter du jour de la main-levé, pur faire annuler la vente, et pour revendiquer la maison. Mais si la maison n'est pas livrée, il n'a pas besoin d'agir. Il attendra que l'acquéreur l'assigne en délivrance; et alors, en quelque temps que ce soit, il opposera l'exception. Avec cette interprétation, le sens de l'article 1304 paroit 
que el vicio no desaparece ${ }^{159}$. Entendido de esta manera, afirma este autor, el artículo 1.304 del Código Civil aparece muy razonable ${ }^{160}$.

Lo dicho se aprecia con mayor claridad cuando se piensa en el objeto o la causa ilícita, pues interpretarlo de otra manera significaría que el paso del tiempo tiene la virtud de tornar lícito lo que en principio fue ilícito, estimamos que no puede haber sido esta la intención del codificador. De esta manera, el saneamiento de la nulidad indica el momento a partir del cual la acción de nulidad no puede ejercerse, porque deja de cumplir el propósito práctico de alterar las consecuencias a que de facto haya dado lugar el acto nulo ${ }^{161}$. En suma, la innovación de A. BELLO en la materia se funda en su aguzado pragmatismo y en la necesaria consolidación de las situaciones fáctico-jurídicas, y consiste en que no consagró una acción meramente declarativa, y por tanto imprescriptible, de nulidad, como sí se admite en otros ordenamientos.

En este punto cabe destacar que, guardando las proporciones, el sistema contemplado por A. BELlo es sustancialmente coincidente con el imperante en países que reconocen expresamente la imprescriptibilidad de la acción de nulidad. Así, el Código Civil italiano señala que la acción para hacer declarar la nulidad es imprescriptible. Sin embargo, quedan a salvo los efectos de la usucapión y de la prescripción de las acciones de repetición (C.C. italiano, art. 1.422). En definitiva, más allá de los plazos de prescripción adquisitiva y extintiva, la declaración de nulidad no tiene la virtud de destruir las consecuencias que de facto se hubieren producido a raíz del acto nulo.

Esa es también la solución ampliamente respaldada por la doctrina y jurisprudencia españolas ${ }^{162}$. En este sentido Díez-PicAzo afirma que "el carácter imprescriptible de la

très-raisonnable, et conforme aux principes». Cfr. DeLvinCourT (1834) p. 597. En suma, la necesidad de sentencia judicial se advierte exclusivamente cuando en la práctica se han producido efectos jurídicos que revertir.

Un análisis exhaustivo sobre el carácter temporal o perpetuo de la excepción de nulidad en el derecho chileno extendería en demasía este trabajo, pero sí cabe notar que la interpretación aquí propuesta conlleva necesariamente a aceptar su carácter perpetuo, pues desde antiguo se ha reconocido que aquello que no puede alegarse por acción, por haber esta prescrito, puede hacerse por excepción sin limitación alguna de tiempo. Lo interesante de este análisis, es que el razonamiento es válido también para la nulidad relativa; por ejemplo, aunque la acción de nulidad por error esté prescrita (4 años desde la celebración del acto), podría paralizarse la acción que exige el cumplimiento del contrato (que dura 5 años) con una excepción de nulidad. En ordenamientos extranjeros esta solución ha sido expresamente regulada por el Código Civil italiano (artículo 1.442: "L'annullabilità può essere opposta dalla parte convenuta per l'esecuzione del contratto, anche se è prescritta l'azione per farla valere").

159 En sus comentarios al hecho de que la nulidad absoluta no puede sanearse, Delvincourt afirma "ne peuvent étre convertes. Masi dans ce cas, quelles est la durée de l'action? L'article 1304 ne distingue pas si l'action en nullité provient de telle ou telle cause. Il ne fixe, pour tous les cas, la durée á dix ans; cela tient au système général du Code, qui veut assurer, autant que possible, la perpétuité des transactions (...). Mais l'exception n'est pas moins perpétuelle». Cfr. Delvincourt (1834) p. 589.

160 Véase Delvincourt (1834) p. 597. Cabe notar que, a pesar de que la doctrina francesa tiene una concepción procesal de la nulidad, pues a partir de la obra de Japiot la considera un derecho a crítica, la imprescriptibilidad de la prescripción no ha dejado de estar presente. Una obra relativamente reciente se ha valido de esta circunstancia para destacar el carácter sustancial y no meramente procesal de la nulidad, en contra de lo sostenido por Japiot y sus seguidores. Vid Thibierge (2010) pp. 341 ss.

161 En palabras de PASQUAU LiAÑo "no es que el contrato haya devenido válido por el trascurso del tiempo, sino que se ha perdido la posibilidad de determinar judicialmente si existe o no la causa de la nulidad, porque quedarán consolidados los efectos que se hayan derivado del contrato”. Cfr. PASQUAU Liaño (2006) p. 5.

162 Por todos, vid Pasquau Liaño (2006) passim. 
acción debe entenderse respecto de la declaración de nulidad, pero no por lo que se refiere a la restitución de las cosas que hubiesen sido dadas, entregadas u obtenidas en virtud del contrato nulo. Los efectos restitutorios están sometidos al plazo normal de prescripción de las acciones personales (...), así como la posibilidad de que las cosas sean usucapidas" 163 .

De esta forma, la gran diferencia entre el sistema chileno y los sistemas italiano y español radicaría en que en Chile no existe una acción civil meramente declarativa de nulidad o inexistencia, sino que toda acción de nulidad lleva aparejados los efectos descritos en los artículos 1.687 y siguientes del Código Civil. En la concepción del legislador, una acción de nulidad solo tiene sentido cuando existan consecuencias fácticas que puedan ser revertidas. De esa manera se explica que el plazo de extinción de la acción de nulidad absoluta coincida con el plazo máximo de prescripción adquisitiva: en origen 30 y actualmente 10 años.

Por último, cabe señalar que en Chile la solución recién reseñada ha sido acogida a propósito de la nulidad de Derecho público. En efecto, los "tribunales se han uniformado en el criterio de que la acción de nulidad de Derecho público es imprescriptible (...). Pero no ocurre lo mismo con las acciones reivindicatorias, restitutorias o de indemnización de perjuicios que se hacen derivar de la acción de nulidad de Derecho público, por cuanto dicen relación con aspectos materiales y patrimoniales"164.

\section{CONCLUSIONES}

La discusión en torno a la llamada teoría de la inexistencia en el Derecho chileno tiene sus orígenes en el Derecho francés y sus principales razones radican en (i) el plazo de saneamiento contemplado en el art. 1.683 C.C.; y (ii) el hecho de que el Código solo atribuye consecuencias a la nulidad judicialmente declarada (art. 1.687). Dadas estas circunstancias, se ha insistido en que las principales diferencias entre la nulidad absoluta y la inexistencia consisten en que la primera requiere sentencia judicial y se sanea por el paso del tiempo, mientras que la segunda opera ipso iure y es insanable.

El origen remoto de tales diferencias se encuentra en el sistema romano de invalidez de los actos, el cual tenía una doble recepción, en Derecho civil y en Derecho pretorio. En

163 Cfr. Díez-Picazo (2007) pp. 578-579. En el mismo sentido se pronuncian incluso algunos defensores de la teoría de la inexistencia al alero del Código de Bello. Los autores Ospina Fernández y Ospina Acosta opinan que "es un error jurídico confundir la ineficacia de la prescripción para darle existencia a un acto que no lo ha sido, con la eficacia de la ella respecto de otras situaciones creadas por hechos o actos diferentes. Así, en nuestro ya trajinado ejemplo de la venta de un bien inmueble por documento privado, seguida de la entrega de la cosa presuntamente vendida y del pago del supuesto precio, constituye un error afirmar que si la prescripción no puede sustituir la escritura omitida, estos otros hechos irregularmente cumplidos quedan perpetuamente expuestos a ser impugnados. No: la entrega de facto de la cosa confiere la posesión al accipiens, y aunque esta sea una posesión irregular por falta de título, lo habilita para adquirir el dominio por usucapión, y la prescripción de la acción de pago de lo no debido también convalida el pago sin causa del precio irregularmente estipulado". Cfr. Ospina y Ospina (1987) pp. 449-450. Idénticamente se ha señalado que "el paso del tiempo no puede volver existente al acto que nunca llegó a configurarse (...). Esto último no excluye que por prescripción adquisitiva se obtenga la consolidación de ciertas circunstancias de hecho" Cfr. Coronel y Del Bruto (2010)

164 Cfr. Pfeffer Urquiaga (2005) p. 144. Sobre el punto véase Jara (2004) pp. 250 ss.; Bocksang (2009) pp. 887-901; Soto Kloss (2013) p. 123; García y Contreras (2014) p. 676. 
Derecho civil, la idea de nulidad expresaba la inexistencia de un acto y operaba ipso iure, en el sentido que no podía ejercerse una actio fundada en un acto nulo y, por tanto, no había lugar a juicio. Junto a esa forma de ineficacia existían remedios pretorios que comportaban la privación de eficacia a un acto civilmente válido. Con la desaparición de la figura del pretor y la unificación de los ordenamientos civil y pretorio, el sistema de nulidades romano dejó de tener una justificación intrínseca, pero el Corpus Iuris conservó vestigios de ambas formas de ineficacia, sin aclarar la razón de su diferente operatividad. Este hecho hizo que durante la vigencia del ius commune los autores intentaran diversos caminos para justificar esas diferencias, pero con escaso éxito. Estas disquisiciones fueron recogidas en el antiguo Derecho francés, que replicaba las discusiones medievales, aunque, como demuestra la obra de Pothier, se llegó a distinguir entre actos nulos (ipso iure) y sujetos a rescisión.

Esta última distinción fue en cierta medida acogida en el Código Civil francés, pero sin una regulación sistemática que permitiera su cabal comprensión; por consiguiente, dio lugar a múltiples interpretaciones. En este panorama se inserta la obra de ZACHARIAE, que agrega a esa bipartición la idea de inexistencia, que funda en la ausencia de elementos fácticos que componen el acto jurídico (además de las solemnidades) y se caracteriza por no necesitar una sentencia judicial que la declare, a diferencia de la nulidad, en cualquiera de sus modalidades. Las ideas de ZACHARIAE tuvieron grandes repercusiones en la doctrina francesa del s. XIX, pero fue abandonada durante el s. XX, para dar paso a una concepción procesal de la nulidad, que la considera un derecho a crítica.

En los términos formulados por ZaCHARIAE, la noción de inexistencia tuvo también repercusión en otros ordenamientos jurídicos y múltiples autores han intentado distinguirla de la nulidad (absoluta, radical o de pleno derecho), sin embargo no existe consenso sobre en qué radicaría la diferencia y, sustancialmente, las características asignadas a la nulidad (absoluta, radical o de pleno derecho) coinciden con las características que la doctrina nacional asigna a la inexistencia. De ahí que pueda afirmarse la equivalencia sustancial entre tales conceptos. Esta constatación tiene importancia por la especial regulación que A. BELLO dio a la nulidad absoluta y resulta útil para interpretar el alcance de las decisiones adoptadas por el legislador.

En efecto, A. BELlo conocía de la equivalencia conceptual entre inexistencia y nulidad absoluta y estaba consciente de su eficacia ipso iure y de su carácter insanable, en contraposición con la nulidad relativa, que daba lugar a la rescisión del acto y podía sanearse, sobre esto existen numerosos testimonios. Sin embargo, conscientemente contempló el saneamiento de la nulidad absoluta y reguló conjuntamente los efectos de la nulidad judicialmente pronunciada. De esta manera, no puede decirse que A. BELlo no haya pensado a la inexistencia como causal de ineficacia, sino más bien hay que aceptar que deliberadamente decidió que la máxima causal de ineficacia reconocida por el ordenamiento jurídico nacional (la única que tiene la virtud de alterar las situaciones fácticas a que da lugar un acto particularmente anómalo) fuera la nulidad absoluta.

La clave para entender el sistema está en aceptar que cuando el artículo 1.683 se refiere al saneamiento de la nulidad absoluta, no alude a la desaparición del vicio que contiene el acto, sino a la extinción de la acción de nulidad, pues el objetivo perseguido por el legislador era posibilitar la consolidación de las relaciones fáctico-jurídicas a que haya 
dado lugar el acto anómalo. En su concepción, la acción de nulidad solo se justifica cuando existan situaciones susceptibles de revertirse. Así se explica que el plazo de extinción de la acción de nulidad absoluta coincida con el plazo máximo de prescripción adquisitiva contemplado en el Código.

En suma, en el Código de A. Bello no cabe hablar de inexistencia como un tipo de ineficacia distinto de la nulidad absoluta, pues el legislador estaba consciente de la equivalencia conceptual entre los dos términos y deliberadamente decidió innovar estableciendo un plazo para el ejercicio de la acción de nulidad absoluta, excluyendo una acción meramente declarativa de nulidad o inexistencia.

Finalmente, resulta una petición de principio sostener que necesariamente debe reconocerse la inexistencia como causal de ineficacia, fundándose en el hecho de que el artículo 1.681 del Código Civil contempla la nulidad exclusivamente en relación a los requisitos de validez del acto y no a los de existencia, en circunstancias que dicha distinción doctrinaria es ajena al Código, que se preocupa más bien de las condiciones que deben cumplirse para que el acto genere efectos jurídicos, y que, atendida la multiplicidad de sentidos con que el Código emplea la expresión valor, no existe razón para sostener que precisamente en este caso se refiere a validez como opuesto a existencia del acto.

\section{BIBLIOGRAFÍA CITADA}

Alcalde Silva, Jaime (2010): "La rescisión en el Código Civil chileno", en Departamento de Derecho Privado Universidad de Concepción, Estudios de Derecho civil V (Santiago, AbeledoPerrot/ LegalPublishing) pp. 47-77.

Alessandri Besa, Arturo (1949): La nulidad y la rescisión en el derecho civil chileno (Santiago, Imprenta Universitaria).

Alessandri Rodríguez, Arturo y otros (2011): Tratado de derecho civil. Parte preliminar y general (Santiago, Editorial Jurídica de Chile, séptima edición).

Atienza Rodríguez, Manuel y Ruiz Manero, Juan (2003): "Seis acotaciones preliminares para una teoría de validez jurídica”, Doxa: Cuadernos de filosofía del derecho, No 26: pp. 719-735.

BaraOna González, Jorge (2005a): "La inexistencia de los actos jurídicos: algunas consideraciones dogmáticas”, en Varas Braun, Juan Andrés y Turner Saelzer, Susan (coordinadores), Estudios de Derecho Civil (Santiago, LegalPublishing) pp. 61-70.

Baraona GonzÁlez, Jorge (2005b): "La nulidad absoluta: ¿opera de pleno derecho?” en Martinic Galetovic, M. D. y Tapia Rodríguez, M. (coordinadores), Sesquicentenario del código civil de Andrés Bello. Presente pasado y futuro de la codificación (Santiago, LexisNexis), t. I, pp. 789-802.

Baraona GonzÁlez, Jorge (2007): "Nulidad; ¿por qué relativa?", en Corral Talciani, Hernán y Rodríguez Pinto, María Sara (coordinadores), Estudios de Derecho Civil II (Santiago, LexisNexis) pp. 539-548.

BARAONA GonZÁlez, Jorge (2012): La nulidad de los actos jurídicos: consideraciones históricas y dogmáticas (Bogotá, Pontificia Universidad Javeriana, Facultad de Ciencias Jurídicas: Grupo Editorial Ibáñez). 
Barcia Lehman, Rodrigo (2012): "Estudio sobre la prescripción y caducidad en el derecho del consumo”, Revista Chilena de Derecho Privado, No 19, pp. 115-163.

Barros Errázuriz, Alfredo (1932): Curso de derecho civil, 4a ed. (Santiago, Nascimento), V. II Bello, Andrés (1981a): "Derecho romano", en Obras Completas de A. Bello, ed. facsimilar, t. XV (Caracas, Fundación La Casa de Bello).

Bello, Andrés (1981b): "Derecho romano", en Obras Completas de A. Bello, ed. facsimilar, t. XVII (Caracas, Fundación La Casa de Bello).

BetTI, Emilio (2002): Teoria generale del negozio giuridico (Napoli, Edizioni Scientifiche Italiane, reimpresión de la segunda edición).

Bianca, C. Massimo (2000): Diritto civile 3. Il contratto (Milán, Giuffrè, segunda edición).

Bocksang Hola, Gabriel (2009): "De las "acciones patrimoniales" derivadas de la nulidad de derecho público", en Arancibia Mattar, Jaime et al., La primacía de la persona (Santiago, LegalPublishing).

Boudot, Michel (2009): "Nullitè, annulation et validation des actes dans la doctrine française des $19^{\circ}$ et $20^{\circ}$ siècles, en Boudot, Michel, Vecchi, Paolo Maria. La théorie des nullités (Paris, LGDJ).

BRUTTI, Massimo (1972): "Invalidità" (storia), en Enciclopedia del Diritto (Milán, Giuffrè) pp. 559-573.

Buigues Oliver, Gabriel (1992): La rescisión de los hechos y actos juridicos en Derecho romano (Valencia, Nomos).

Casado Casado, Belen Maria (2006): "El art. 6.3 C.C., ¿punto de partida para el establecimiento de un régimen sancionador en el Código Civil?” Disponible en: http://www. codigo-civil.info/nulidad/lodel/document.php?id=229

Cifuentes, Santos (1986): Negocio jurídico. Estructura. Vicios. Nulidades (Buenos Aires, Editorial Astrea).

Claro Solar, Luis (1979): Explicaciones de derecho civil chileno y comparado, [1939] ed. Facsimilar, Tomo VI (Santiago, Editorial Jurídica de Chile).

CoIng, Helmut (1996): Derecho privado europeo (trad. y apostilla de Antonio Pérez Martín, Madrid, Fundación Cultural del Notariado).

Concha Machuca, Ricardo (2014): "Nulidad y obligaciones naturales: la obligación de restituir contra el derecho a retener en el Código Civil de Bello", Revista de Derecho Privado, Universidad Externado de Colombia, No 26, enero-junio de 2014: pp. 255-266.

Coronel Jones, César y Del Bruto Andrade, Óscar (2011): "Nulidad e inexistencia de los actos jurídicos en el derecho ecuatoriano", Ius Humani Revista de Derecho, Vol. 2, disponible en: http://www.uhemisferios.edu.ec/revistadederecho/index.php/iushumani/ article/download/19/pdf_1

De Castro y Bravo, Federico (1985): El negocio jurídico (Madrid, Civitas, edición facsimilar).

De los Mozos, José Luis (2005): "Inexistencia, nulidad y anulabilidad en el Anteproyecto de Código europeo de contratos de la Academia de Pavía", en Nul: Estudios de validez e ineficacia, disponible en: http://www.codigo-civil.info/nulidad/lodel/document.php?id=58

Delgado Echeverria, Jesús (2005): "El concepto de validez de los actos jurídicos de Derecho privado. (Notas de teoría y dogmática)", Anuario de Derecho Civil, vol. 58 No 1: pp. 9-74. 
Delgado Echeverria, Jesús (2006a): “"Sanción de invalidez”? Los conceptos de invalidez y de sanción”, Estudios sobre invalidez e ineficacia, No 1, Disponible en: http://www. codigo-civil.info/nulidad/lodel/document.php?id=249

Delgado Echeverria, Jesús (2006b): "Las leges irritantes en De Legibus de Francisco Suárez como normas de competencia”, Doxa. Cuadernos de filosofía del derecho, No 29: pp. 405-421.

Delgado Echeverria, Jesús, Parra LucÁn, María Ángeles (2005): Las Nulidades de los contratos: en la teoría y en la práctica (Madrid, Dykinson).

Delvincourt, M. (1834): Cours de code civil, t. II (Dijon, Victor Lagier, Libraire; París, Chez Videcoq, Libraire).

Di Paola, Santi (1966): Contributi ad una teoria della invalidità e della inefficacia in diritto romano (Milán, Giuffrè).

Díez-Picazo, Luis (2007). Fundamentos de derecho civil patrimonial. Introducción teoría del contrato (Madrid, Civitas-Thomnson Reuters, sexta edición).

Domat, Jean (1844): Las leyes civiles en su orden natural (trad. castellana de Felio Covarrubias y José Sardá, Barcelona, Imprenta de José Taulo, segunda edición).

Domínguez Águila, Ramón (2012): Teoría general del negocio jurídico (Santiago Editorial Jurídica de Chile, segunda edición).

Ducci Claro, Carlos (1988): Derecho civil. Parte general (Santiago, Editorial Jurídica de Chile, tercera edición).

FABRES, José Clemente (1908): “De la nulidad y rescisión”, en Obras completas de don José Clemente Fabres, t. III (Santiago, Imprenta Cervantes).

FalzeA, Angelo (1962): "Efficacia Giuridica", en Enciclopedia del Diritto, t. XXII (Milán, Giuffrè) pp. 433-509.

Fauvarque-Cosson, Bénédicte, Mazeaud, Denis (2008): European contract law: materials for a common frame of reference: terminology, guiding principles, model rules (Munich, Sellier European Law Publishers).

Flume, Werner (1998): El Negocio Jurídico (trad. castellano de José María Miquel González y Esther Gómez Calle, Madrid, Ed. Fundación Cultural del Notariado, cuarta edición).

Galgano, Francesco (2012): Diritto privato, reimpresión con apéndice (Padova, CEDAM)

García Goyena, Florencio (1852): Concordancias, motivos y comentarios del Código Civil español, t. III (Madrid, Imprenta de la Sociedad Tipográfico-Editorial).

García Pino, Gonzalo y Contreras Vásquez, Pablo (2014): Diccionario constitucional chileno. Cuadernos del Tribunal Constitucional, No 55 (Santiago, Tribunal Constitucional)

GAUdET, Serge (1995): "Inexistence, nullité e annulabilité du contrat: essai de synthése“, en Revue de Droit de Mc. Gill, vol. 40: pp. 291-363.

Ghestin, Jacques (1988): Traité de droit civil. Les obligations. Le contrat: formation (Paris, LGDJ, segunda edición).

Guerra Fernández, Juan (2003): "Sobre las causas de nulidad de los contratos privados", disponible en: http://libros-revistas-derecho.vlex.es/vid/causas-nulidad-contratos-privados-192054

GuZmán BRito, Alejandro (2013): Derecho privado romano (Santiago, LegalPublishingThomnson Reuters, segunda edición). 
Hinestrosa, Fernando (2006): Del contrato, de las obligaciones y de la prescripción Ante-proyecto de Reforma del Código Civil francés Libro III, títulos III y XX (Bogotá, Universidad Externado de Colombia).

Iglesias, Juan (2001): Derecho romano (Barcelona, Ariel, decimotercera edición).

Infante Ruiz, Francisco y Oliva Blázquez, Francisco (2009): "Los contratos ilegales en el derecho privado europeo", disponible en: http://www.indret.com/pdf/653_es.pdf

JAPIOT, René (1909): Des nullités en matière d'actes juridiques: essai d'une théorie nouvelle (Paris, Librairie Nouvelle de Droit et de Jurisprudence).

Jara Schnettler, Jaime (2004): La nulidad de derecho público ante la doctrina y la jurisprudencia (Santiago, Editorial Libromar).

KASER, Max (1982): Derecho privado romano. Versión directa de la 5a ed. Alemana por José Santa Cruz Teijeiro (Madrid, Reus, segunda edición).

KLEINE, Jean-Philippe (2010): Die Unwirksamkeit von Verträgen nach französischem Recht (Hamburgo, Max Planck Institute für ausländisches und internationales Privatrecht).

Lecaros Arthur, Blanca (1997): La inexistencia en el código civil chileno. Tesis para optar al grado de licenciado en derecho de la Pontifica Universidad Católica de Chile. Director: Raúl Lecaros Zegers (Santiago, Pontificia Universidad Católica de Chile).

Masi, Antonio (1978): Voz "Nullità (storia)", en Enciclopedia del diritto, XXVIII (Milán, Giuffrè).

MARTín PÉRez, José Antonio (1995): La rescisión del contrato: en torno a la lesión contractual y el fraude de acreedores (Barcelona, Bosch).

Morales Herevias, Rómulo (2005): "Inexistencia y nulidad analizadas desde el punto de vista de los derechos italiano, español y peruano”, en Estudios sobre invalidez e ineficacia. Nulidad de los actos jurídicos, disponible en: http://www.codigo-civil.info/nulidad/lodel/ document.php?id=129

Ospina Fernández, Guillermo, Ospina Acosta, Eduardo (1987): Teoría general de los actos o negocios jurídicos (Bogotá, Temis, tercera edición).

Parra LuCÁn, María Ángeles (2004): "Las anomalías del contrato invalidez e ineficacia en el anteproyecto de Código Europeo de Contratos. Estudio comparado con el Derecho Español. (Aproximación a la Sección 1 del Título XI de la Parte General del Código Europeo de Contratos)", Anuario de Derecho Civil, vol. 57: pp. 549-638.

Parra LuCÁn, María Ángeles (2010): “Conceptos jurídicos”, en Cuadernos Prácticos Bolonia. Obligaciones y contratos. Cuaderno II. Eficacia e ineficacia del contrato, disponible en: http://libros-revistas-derecho.vlex.es/vid/conceptos-juridicos-315228822

PASQUaU Liaño, Miguel (1997): Nulidad y anulabilidad del contrato (Madrid, Civitas).

Pasquau Liaño, Miguel (2006): "La acción de nulidad sí prescribe", en Nulidad: estudios sobre invalidez $e$ ineficacia, disponible en: http://www.codigo-civil.info/nulidad/lodel/ document.php?id=288

Pescio, Victorio (1958): Manual de derecho civil. Teoría general de los actos jurídicos y teoría general de la prueba, tomo II (Santiago, Editorial Jurídica de Chile).

Pfeffer Urquiaga, Emilio: "La nulidad de derecho público; tendencias jurisprudenciales", Revista de Derecho Público, vol. 67: pp. 144 ss. 
Philippi, Julio (1999): Notas sobre nulidad e inexistencia en nuestro Código Civil, publicado en Anales Jurídico-Sociales, No 4, pp. 15-23. Ahora disponible en "Escritos y Documentos de Julio Philippi", disponible en: http://www.cepchile.cl/dms/archivo_1138_804/rev74_fontaine_sierra.pdf

Planiol, Marcel (1903): Traité élémentaire de Droit civil (Paris, Cotillon, segunda edición).

Pothier, Robert Joseph (2007): Tratado de las obligaciones (trad. castellana de Guillermo Cabanellas de Torres, Buenos Aires, Heliasta).

Puga Vial, Juan Esteban (2011): La Sociedad Anónima y otras sociedades por acciones en el Derecho chileno y comparado (Santiago, Editorial Jurídica de Chile).

Ramón Fernández, Francisca (2012): "Conceptualización de la ineficacia, invalidez e inexistencia en el derecho español”, Revista Chilena de Derecho Privado, No 19, pp. 63 ss.

Renard, Claude, Vieujean, Edouard (1963): "Nullitè, inexistence et annulabilitè en droit civil Belge“, Revue de la Faculté de droit de l'Université de Liège, año 1962: pp. 243-294.

Robleda, Olis (1964): La nulidad del acto jurídico (Roma, Librería Editrice dell'Università Gregoriana, segunda edición).

Rodríguez Grez, Pablo (1995): Inexistencia y nulidad en el código civil chileno (Santiago, Editorial Jurídica de Chile).

San Martín Neira, Lilian (2013): "Responsabilidad precontractual por ruptura injustificada de negociaciones", Revista Chilena de Derecho, vol. 40 No 1: pp. 315-322.

SAnfilippo, Cesare (2002): Istituzioni di diritto romano (Soveria Mannelli, Rubbettino, décima edición).

Sото KLOSS, Eduardo (2013) "La nulidad de derecho público en la jurisprudencia reciente", en Ius Publicum, No 30: pp. 107-123.

Talamanca, Mario (1990): Istituzioni di diritto romano (Milán, Giuffrè).

Talamanca, Mario (1998); "Inesistenza, nullità ed ineficacia dei negozi giuridici nell'esperienza romana", en Bullettino dell'istituto di diritto romano, vol. CI-CII.

Talamanca, Mario (2013): Elementi di diritto privato romano (Milán, Giuffrè, segunda edición).

Thibierge, Catherine (2010); Nulidad, restituciones y responsabilidad, traducción de Gustavo de Greiff (Bogotá, Universidad Externado de Colombia)

Tommasini, Raffaele (1972): Voz "Invalità (dir. privato)", en Enciclopedia del diritto, XXVIII (Milán, Giuffrè) pp. 575-597.

Tommasini, Raffaele (1978): Voz "Nullità (dir. privato)", en Enciclopedia del diritto, XXVIII (Milán, Giuffrè).

Vera, Robustiano (1892): Código Civil de la República de Chile. Comentado y Explicado, t. I (Santiago, Imprenta Gutenberg).

Vial del Río, Víctor (2003): Teoría general del acto jurídico (Santiago, Editorial Jurídica de Chile, quinta edición).

Vodanovic, Antonio (1945): Curso de derecho civil. Basado en las explicaciones de los profesores de la Universidad de Chile, Arturo Alessandri Rodríguez y Manuel Somarriva Undurraga (Santiago, Editorial Nascimento, segunda edición).

Vodanovic, Antonio (1945): Curso de derecho civil. Basado en las explicaciones de los profesores de la Universidad de Chile, Arturo Alessandri Rodríguez y Manuel Somarriva Undurraga (Santiago, Editorial Nascimento, segunda edición). 
ZaChariaE, M. C. S (1843-1846): Cours de droit civil français. Revu et augmenté, avec l'agrément de l'auteur par MM. C. AubrY et C. RAU (Strasbourg, F. Lagier, segunda edición).

Zimmermann, Reinhard (1996): The law of obligations (Oxford, Oxford University Press).

\section{JURISPRUDENCIA CITADA}

Román COn Maturana (1914): Corte Suprema, 21 de junio de 1914, Revista Derecho y Jurisprudencia, T. XVI, 1919, segunda parte, secc. $1^{\circ}$, pp. 1-11.

CorRea CON CORREA (1922): Corte Suprema, 11 de noviembre de 1922, Revista Derecho y Jurisprudencia, T. XXI, 1924, segunda parte, secc. $1^{\circ}$, p. 973-980.

LLONA CON CARMONA (1931): Corte Suprema, 6 de noviembre de 1931, Gaceta de los Tribunales, $2^{\circ}$ semestre, No 42, pp. 222-229 (Voto de Minoría).

Ríos CON NAUDON (1936): C. de Santiago, 4 de agosto de 1936, Revista Derecho y Jurisprudencia, T. XXXIV, 1937, segunda parte, secc. $2^{\circ}$, pp. 70-80.

GEISSE CON MURÚA (1942): Corte Suprema, 19 de agosto de 1942, Revista Derecho y Jurisprudencia, t. XLIV, segunda parte, secc. $1^{\circ}$, 1942, pp. 76-86.

TORRES CON FISCO (1945): Corte Suprema, 4 de abril de 1945, Revista Derecho y Jurisprudencia, T. XLII, 1945, segunda parte, secc. $1^{\circ}$, pp. 558-559.

SÁNCHEZ CON VALENZUELA (1945): C. de Chillán, 27 de septiembre de 1945, Revista Derecho y Jurisprudencia, T. XLIII, 1946, segunda parte, secc. $2^{\circ}$, pp. 38-42.

Romero y OTRO CON CORTÉS Y OTRO (1954): Corte Suprema, 20 de octubre de 1954, Revista Derecho y Jurisprudencia, T. LI, segunda parte, secc. $1^{\circ}, 1954$, p. 483.

Banco Alemán Transatlántico con Banco Estado de Chile (1964): C. de Santiago, 5 de marzo de 1964. Revista Derecho y Jurisprudencia, T. LXII, segunda parte, secc. $2^{\circ}$, 1965, pp. 53-63.

MuÑOZ CON RAmOS Y OTRA (1966): C. de Valparaíso, 17 de septiembre de 1966, Revista Derecho y Jurisprudencia, T. LXIII, pp. 67-101.

SELMAN D., PEDRO (Recurso de queja) (1967): Corte Suprema, 15 de septiembre de 1967, Revista Derecho y Jurisprudencia, T. LXIV, 1967, segunda parte, secc. $1^{\circ}$, pp. 304-305;

Guajardo con Campos (1981): C. de San Miguel, 8 de mayo de 1981, Revista Derecho y Jurisprudencia, T. LXXVIII, 1981, segunda parte, secc. $2^{\circ}$, pp. 93-95.

Marchant CON Cancino (1985): C. de San Miguel, 10 de junio de 1985, Gaceta Jurídica No 60, 1985, pp. 73-82.

CARRASCO CON BANCo UNIDO DE FOMENTo (1990): C. de Santiago, 23 de marzo de 1990, Revista Derecho y Jurisprudencia, T. LXXXVII, 1990, p. 69.

BANCO DEL Estado DE ChILE CON SAUTERel (1991): Corte Suprema, 4 de septiembre de 1991, Fallos del Mes No 394, p. 445.

Sociedad Ingenieros y Construcciones Rimesas S.A. con Muñoz (1995): C. de Concepción, 11 de abril de 1995, LegalPublishing, Rol 315-1994.

Jaras CON UNIVERSIDAD DE ChILE (1997): C. de Santiago, 2 de mayo de 1997, Gaceta Jurídica No 203, 1997, p. 107.

WEISSENBERG Y OTRO CON KUBORN Y OTRO (2009): Corte de Santiago, 14 de agosto de 2009, LegalPublishing, Rol No 5583-2007. 
CASTRO CON ESPINOZA (2010): C. Rancagua, 26 de agosto de 2010, LegalPublishing, Rol 734-2009.

MANSOOR CON DE LA BARRERA (2011): Corte Suprema, 31 de mayo de 2011, Base Jurisprudencial del Poder Judicial, Rol 271-2010.

ZúNIGA CON FLORES (2011): C. de Santiago, 18 de noviembre de 2011, LegalPublishing, Rol 5168-2010.

Agrícola Pecuaria S.A. con Agrícola Super Limitada (2012): Corte Suprema, 28 de noviembre de 2012, Base Jurisprudencial del Poder Judicial, Rol 4537-2010.

Gonzalez Freire WynNifred con Doneaud Catalán (2013): Corte de Apelaciones de Santiago, 14 de junio de 2013, LegalPublishing, Rol 5710-2011.

\section{LEGISLACIÓN CITADA}

Código Civil argentino (1865)

Código Civil chileno (1855)

Código Civil español (1889)

Código Civil francés (1804)

Código Civil italiano (1942)

DL 2.695 del 30 de mayo de 1979, sobre la regularización de la posesión de la pequeña propiedad raíz y para la constitución del dominio sobre ella.

Ley No 18.046 del 22 de octubre de 1981, sobre Sociedades Anónimas. 